\begin{abstract}
National economic policies' effects on growth were over-emphasized in the early literature on endogenous economic growth. Most of the early theoretical models of the new growth literature (and even their new neoclassical counterparts) predicted large policy effects, which was followed by empirical work showing large effects. A reappraisal finds that the alleged association between growth and policies does not explain many stylized facts of the postwar era, depends on the extreme policy observations, that the association is not robust to different estimation methods (pooled vs. fixed effects vs. cross-section), does not show up as expected in event studies of trade openings and inflation stabilizations, and is driven out by institutional variables in levels regressions
\end{abstract}


National Policies and Economic Growth: A Reappraisal

\author{
May 2003 \\ William Easterly \\ New York University \\ Center for Global Development
}




\section{National Policies and Economic Growth: A Reappraisal}

An influential study by World Bank researchers Paul Collier and David Dollar (2001) finds that policy reform in developing countries would accelerate their growth and cut world poverty rates in half. They conclude that

Poverty reduction - in the world or in a particular region or country - depends primarily on the quality of economic policy. Where we find in the developing world good environments for households and firms to save and invest, we generally observe poverty reduction.

I find the audacious claim that policy reform can cut world poverty in half a little daunting even more so since Collier and Dollar base their results on an unpublished growth regression by me! (Like firearms, it is dangerous to leave growth regressions lying around.)

The International Monetary Fund (2000) also claims that "Where ssound macroeconomic \} policies have been sustained, they have raised growth and reduced poverty." These claims are often held out as hope to economically troubled continents like Africa: "Policy action and foreign assistance ... will surely work together to build a continent that shows real gains in both development and income in the near future." Unfortunately, this claim was made in World Bank (1981) and the "real gains" in Africa have yet to arrive as of 2003.

Do the ambitious claims for the power of policy reform find support in the data? Are they consistent with theoretical views of how policy would affect growth?

The large literature on the determinants of economic growth, beginning with Romer (1986), has intensively studied national economic policies as key factors influencing long run growth. In this chapter, I take a look the state of this literature today, both theoretical and empirical. I do not claim to comprehensively survey the literature. I focus the chapter on the question of how strong is the case that national economic policies (by which I mean mainly macroeconomic and trade policies) have economically large effects on the growth rate of economies.

I am in the end skeptical that national policies have the large effects that the early growth literature claimed, or that the international agencies claim today. Although extremely bad policy can probably destroy any chance of growth, it does not follow that good macroeconomic or trade 
policy can create the conditions for high steady state growth.

\section{Theoretical models that predict strong policy effects}

The simplest theoretical model of endogenous growth is the AK model of Rebelo (1991).

Rebelo postulated that output could be proportional to a broad concept of capital $(\mathrm{K})$ that included both physical and human capital:

(1) $\mathrm{Y}=\mathrm{AK}$

In principle, $\mathrm{K}$ could also include any kind of stock of knowledge, technology, or organizational technique that can be built up over time by sacrificing some of today's consumption to accumulate such a stock. For example, technological knowledge could be accumulated by diverting some of today's output into lab equipment or other machines that help make new discoveries feasible. Or knowledge or human capital itself could be used to create further knowledge or human capital rather than producing today's output. ${ }^{1}$ However, unlike many other endogenous growth models that explicitly address knowledge or technology (e.g. Aghion and Howitt 1998), $\mathrm{K}$ is treated in this model as a purely private good - both excludable and rival. I will address below what happens when we relax this assumption. ${ }^{2}$

Constant returns to the factors that can be accumulated is also a key assumption in this model's prediction of a constant steady state rate of growth for given parameters and policies. This would rule out fixed costs in implementing a new technology, or increasing returns to accumulation at low levels of $\mathrm{K}$, both of which feature in other growth models.

\footnotetext{
${ }^{1}$ Rebelo 1991 showed that as long as the capital formation function itself has constant returns to accumulated factors, endogenous growth is possible even if final production has diminishing returns to capital.

${ }^{2}$ Since $\mathrm{K}$ in my models can always represent either technology or factor accumulation, I do not address the hot debate on how much factor accumulation matters for growth. On education, Benhabib and Spiegel (1994) and Pritchett (1996) shows that cross-country data on economic growth rates show that increases in human capital resulting from improvements in the educational attainment of the work force have not positively affected the growth rate of output per worker. It may be that, on average, education does not effectively provide useful skills to workers engaged in activities that generate social returns. There is disagreement, however. Krueger and Lindahl (1999) argue that measurement error accounts for the lack of a relationship between growth per capita and human capital accumulation. Hanushek and Kimko (2000) find that the quality of education is very strongly linked with economic growth. However, Klenow (1998) demonstrates that models that highlight the role of ideas and productivity growth do a much better job of matching the data than models that focus on the accumulation of human capital. More work is clearly needed on the relationship between education and economic development. On physical capital accumulation, there is the debate between the "neoclassical" school stressing factor accumulation (Mankiw, Romer, Weil 1992, Mankiw 1995, Young 1995) and the school stressing technology or the residual (Klenow and Rodriguez-Clare 1997a,b), Hall and Jones 1999, Easterly and Levine 2001).
} 
Since $\mathrm{K}$ is purely a private good, there is no role for government in this model. The market equilibrium yields the first best solution, and any government intervention in the form of taxes or price distortions must worsen welfare.

In this model, policies like tax rates have large effects on steady state growth. Consider first a tax $(\tau)$ on the purchase of investment goods (I). Consumption (C) is given by output less investment spending and taxes:

(2) $\mathrm{C}=\mathrm{Y}-(1+\tau) \mathrm{I}$

Suppose the population size is constant and each (identical) household - dynasty maximizes welfare over an infinite horizon:

(3) $\max \int_{0}^{\infty} e^{-\rho t} C^{1-\sigma} /(1-\sigma) d t$

(4) $\dot{K}=I-\delta K$

Then the consumer-producer would invest at a rate that results in steady-state growth of

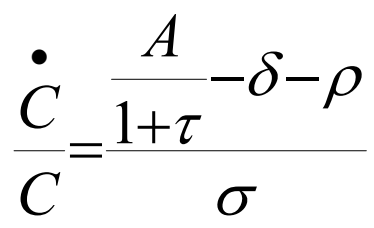

Here policy has large effects on steady state growth. If $A=.15$ and $\sigma=1$, then an increase from a tax rate of 0 to one of $30 \%$ would lower growth by 3.5 percentage points. Such a policy pursued over 30 years would leave income at the end 65 percent lower than it would have been in the absence of a tax. This is a strong claim for the effects of policy on economic development! It offers a possible explanation for the poverty of a poor nation - bad government policies (high $\tau$ )which can be remedied easily enough by changing to good policies (low $\tau$ ). It is clear why this has been a seductive theory for aid agencies and policymakers that seek to promote economic development.

Before examining this claim in more detail, note that the tax rate on investment goods does not have to be an explicit tax on capital goods. First of all, there is an equivalent income tax that would have had the same effect on growth (given by $\mathrm{t}=1-1 /(1+\tau)$ ), so policies here could be any government action that diverts income away from the original investor in production. Second, the tax on capital goods could stand for any policy that alters the price of investment 
goods relative to consumption. ${ }^{3}$ For example, suppose that a populist government controls output prices for consumers but the investor must buy goods for investment on the black market. Then the premium of the black market price over the official price would act much like a tax on investment goods. If the one good in this model is tradeable, then the black market premium on foreign exchange might be a good proxy for the wedge between official output prices and black market investment good prices (assuming that consumer goods can be imported at the official exchange rate, or at least that official output prices are controlled as if they could be). If we suppose that the purchaser of investment goods must hold cash in advance of a purchase of investment goods, then inflation would be indirectly be a tax on investment goods. One could also get similar results with institutional variables -- a probability of expropriation of part or all of the capital good by the government or government officials demanding a bribe every time a new unit of capital is installed would act much like a tax on investment.

The claims for large policy effects become even stronger in growth models with increasing returns to capital and externalities. Suppose that there is a group of large but fixed size where the capital held by each member of the group has non-pecuniary externalities for the rest of the group. For example, a high human capital individual in a residential neighborhood might benefit the rest of the neighborhood with whom she socially interacts. The knowledge and connections that this individual brings might raise the productive potential of others (this is loosely what is called "social capital" in the literature). If this is true for all social interactions in the neighborhood, and these interactions are identical, costless, and exogenous for all members, then there will be a spillover from the average human capital of the neighborhood to each inhabitant of the neighborhood. The production function for an individual member would look like this:

(6) $y=A k^{\alpha} \bar{k}^{\beta}$

One can think of other similar examples of spillovers. If $\mathrm{k}$ includes knowledge or technology, it is plausible that these goods are non-rival and partially non-excludable. For example, firms may benefit by example from new technology installed by other firms in the same trade. People in

\footnotetext{
${ }^{3}$ Chari, McGrattan, and Kehoe 1996 and McGrattan and Schmitz 1999 present models and empirical work emphasizing the measured high relative price of capital goods as a policy factor inhibiting economic development. Hsieh and Klenow 2003 have an alternative story that stresses high capital prices and low income as the joint
} 
almost every human activity engage in "shop talk" that is incomprehensible to outsiders, but which apparently conveys productive knowledge to those involved in the activity. ${ }^{4}$

Assuming the same maximization problem as above (equations (2) through (4)), then the individual will invest in k taking everyone else's investment as given (because the group is too large for her to influence its average). The optimal path of consumption is now given by

(7) $\frac{\dot{C}}{C}=\frac{\frac{A \alpha k^{\alpha-1} \bar{k}^{\beta}}{1+\tau}-\delta-\rho}{\sigma}$

However, since all members of the group are assumed to be identical, then $\mathrm{k}=\bar{k}$ ex-post, and the growth rate for each individual will be

(8) $\frac{\dot{C}}{C}=\frac{\frac{A \alpha \bar{k}^{\alpha+\beta-1}}{1+\tau}-\delta-\rho}{\sigma}$

There are multiple equilibria if $\alpha+\beta-1>0$, i.e. if both the original importance of broad capital to production is large plus there are strong spillovers. If we have the special case of $\alpha+\beta=1$, then we are back to the AK model, albeit one with suboptimal market outcomes because of the externality. If $\alpha+\beta-1<0$, then the model will feature similar prediction as the neoclassical model with a high capital share (discussed below).

In the multiple equilibria case, the return to capital increases the more initial capital there is, the opposite of the usual diminishing returns to capital. Figure 1 illustrates the possible outcomes. If the tax rate is low, the after tax rate of return to capital is the upper upward-sloping line. Any initial capital stock to the left of point A (where the after tax return is less than $\delta+\rho$ ) will go into a vicious circle of negative growth of consumption and decumulation of capital. Any point to the right of A (such as B) will go into a virtuous circle of positive and accelerating growth of consumption and positive capital accumulation. ${ }^{5}$ Now suppose that tax rates are

outcome of a technological disadvantage in producing tradeable goods (including capital goods) in poor countries.

${ }^{4}$ The emphasis on the special properties of knowledge and technology was highlighted by Romer 1994 and Aghion and Howitt 1999. The idea of social capital has been stressed by authors such as Putnam (1993, 2000), Glaeser 2000, Narayan and Pritchett 1997, Narayan and Woolcock 2001

${ }^{5}$ The feature of ever accelerating growth in this model leads to nonsensical predictions in the long run - the model would have to be modified at higher incomes with some feature that puts a ceiling on the rate of return to capital. 
increased, shifting the rate of return to the lower upward-sloping line in Figure 1. Now any point to the left of $\mathrm{C}$ will go into a vicious circle of decline. An economy with capital stock $\mathrm{B}$, which was in the expanding region under low taxes, is now in the declining region under high taxes. A policy shift now has an even more dramatic impact on national prosperity - it could spell the difference between subsistence consumption (say Mali) and industrialization (say Singapore). Policy spells the difference in the long run between per capita income of $\$ 300$ and $\$ 30,000-$ rather a dramatic effect. As in all multiple equilibria models, initial conditions matter and small things (like policy) can have large consequences. If the first endogenous growth model was seductive to policymakers, this is even more so - one government official at the stroke of a pen could change a nation's prospects from destitution to prosperity.

This increasing returns model is much like poverty trap models like those of Azariadis and Drazen (1991), Becker, Murphy, and Tamura (1990), Kremer (1993), and Murphy, Shleifer, and Vishny (1989). It is also consistent with models of in-group ethnic and neighborhood externalities (Borjas 1992, 1995, 1999, Benabou 1993, 1996) and geographic externalities (Krugman 1991, 1995, 1998, Fujita, Krugman, and Venables 1999). Ades and Glaeser (1995) present evidence for increasing returns in closed economies.

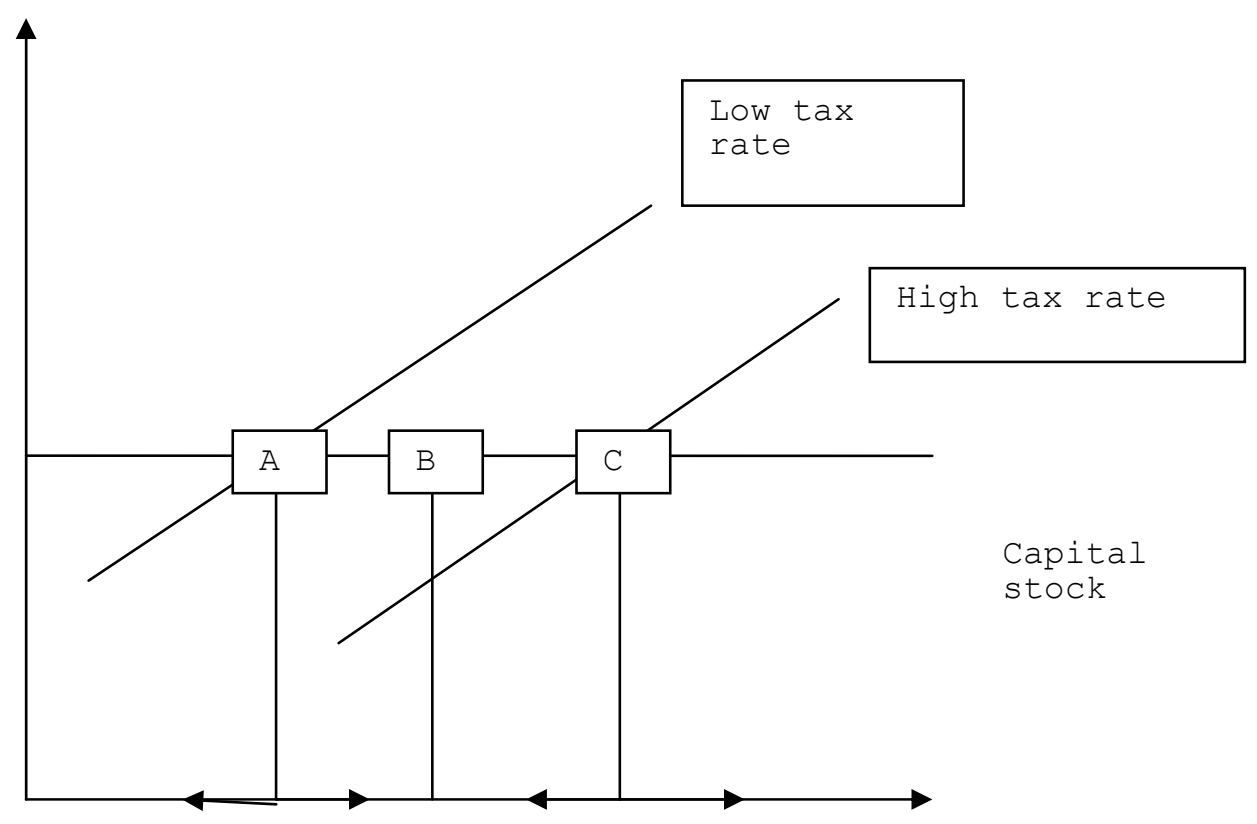

Figure 1: Multiple equilibria with increasing returns to capital, alternative tax regimes 
A story like that told in figure 1 would also predict instability of growth rates if an economy is in the middle region B and is subject to continuous fluctuations in policies. The economy would keep shifting from positive to negative growth and back again as policies change. This is a possible story for some of the spectacular reversals in output growth that we have seen in countries like Cote d'Ivoire, Jamaica, Guyana, and Nigeria (see Figure 4).

Figure 4: Examples of variable per capita income over time

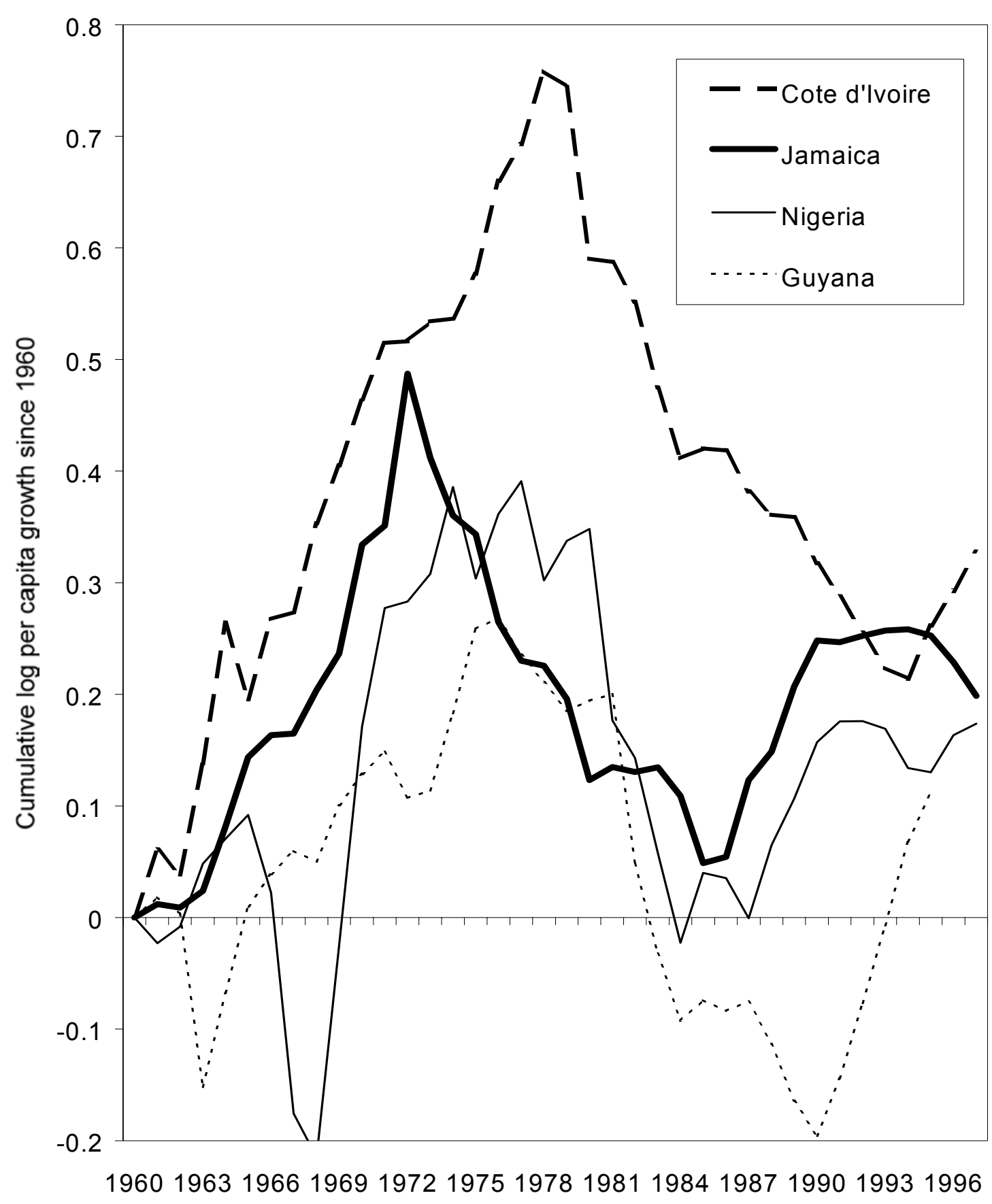


It is often assumed that these strong claims for policy effects on growth are only a feature of endogenous growth models. However, the other innovation in the growth literature of the last two decades has been to put a much higher weight on capital even in the neoclassical exogenous growth model. Again, the justification is that capital is a broader concept than just physical equipment and buildings. It should include at least human capital, if not the more exotic forms of capital discussed above. Attributing part of the labor income in the national accounts to human capital, this would raise the share of capital in output from around 1/3 (if the only form of capital was physical) to something like $2 / 3 .^{6}$

The neoclassical production function with labor-augmenting technological change is:

(9) $\mathrm{Y}=\mathrm{K}^{\alpha}(\mathrm{AL})^{1-\alpha}$

In per capita terms, we have:

(10) $\mathrm{y}=\mathrm{k}^{\alpha} \mathrm{A}^{1-\alpha}$

The consumer-producer's maximization problem is the same as before, using equations (2) through (4). Technological progress (the percent growth in A) is assumed to take place at an exogenous rate $\mathrm{x}$. As is well known, accumulation of physical and human capital cannot sustain growth in the long run in the absence of technological progress. Since policy affects the outcome only through the incentive to accumulate capital, it follows that policy by itself cannot foster sustained growth in this model. With growth in A of $\mathrm{x}$, the long-run steady state will have per capita output y, capital per worker $\mathrm{k}$, and per capita consumption all growing at the same (exogenous) rate $\mathrm{x}$. The tax rate on capital goods has no effect on the steady-state growth rate. However, policy does have potentially large effects on the level of per capita income. To see this, it is convenient to write both capital per worker and per capita income relative to the technological level A. The optimal growth of per capita consumption is now:

(11) $\frac{\dot{C}}{C}=\frac{\frac{\alpha\left(\frac{k}{A}\right)^{\alpha-1}}{1+\tau}-\delta-\rho}{\sigma}$

Since (11) must equal $\mathrm{x}$ in steady state, an increase in the tax rate $\tau$ must always be offset by a decrease in the relative capital stock (raising the pre-tax rate of return to capital because of

\footnotetext{
${ }^{6}$ Mankiw, Romer, Weil 1992 and Mankiw 1995.
} 
diminishing returns, i.e. because $\alpha<1$ ). Setting (11) equal to $\mathrm{x}$ determines the $\mathrm{k} / \mathrm{A}$ ratio in the steady state, which in turn gives the following for per capita income relative to technology:

$$
\text { (12) } \frac{y}{A}=\left[\frac{\alpha}{(1+\tau)(\sigma x+\delta+\rho)}\right]^{\frac{\alpha}{1-\alpha}}
$$

A high tax on investment inhibits capital accumulation and thus lowers the level of income relative to the technology level. High taxes are still a possible explanation of relative poverty in the neoclassical model. With a capital share of 2/3 (including both human and physical capital), a tax rate decrease from 50 percent to zero raises income by a factor of $(1.5)^{2}$, or 2.25 times. If the capital share were 0.8 (as writers like Barro and Mankiw have suggested), then the tax reduction would raise income by a factor of $(1.5)^{4}$ or 5 times.

Although there is no effect of the tax change on steady state growth, there will be a dramatic change in growth in the transition from one policy regime to another. There is one unique saddle path to the new steady state; consumption will jump to that saddle path after the change in policy (in a world of perfect certainty of course). To solve for the transition involves solving for the saddle-path of consumption in transition to the new steady state. Figure 2 shows a simulation of a decrease in the tax rate on investment from 50 percent to zero, with the following parameter values:

\section{Parameters}

$\begin{array}{lr}\text { alpha } & 0.6666 \\ \text { delta } & 0.07 \\ \text { rho } & 0.05 \\ \text { sigma } & 0.9 \\ \mathrm{x} & 0.02\end{array}$

For comparison, I also show a simulation of an endogenous growth rate model with $\mathrm{A}=.138$, which gives the same 2 percent per capita growth rate at zero tax as the exogenous growth neoclassical model. Both models show dramatic growth rate effects after the policy change, still large after 20 to 30 years. It is only in the very long run that the neoclassical growth effect wears off with diminishing returns. Investment rates would show similar jumps after the policy change 
as growth rates.

What is different for the purposes of empirical work is that the predicted difference in growth rates in the endogenous growth model before and after the tax decrease could equally apply to cross-section differences in growth between high-tax and low-tax countries. In the neoclassical model, the predicted effect of policy change on growth is only for a cross-time effect within countries. However, this difference has been handled in practice by testing the effect of current policies on growth, controlling for initial income. Initial income can be thought of as representing policy regimes prior to the period under study. If current policy predicts a higher steady state level of income than initial income, then the transitional dynamics like those shown in figure 2 will be set in motion. The neoclassical model would predict instability of growth rates over time if frequent policy changes shift the steady state level above or below the current income level, which is ironically similar to the increasing returns prediction of growth rate instability.

One big difference between the three models is that the neoclassical model predicts falling growth and investment after the initial policy-induced increase in growth, the increasing returns to capital model predicts rising growth and investment afterwards, while the constant returns to capital model predicts constant growth. I will examine some case studies of major policy reforms below to see which of these predictions appears to hold.

All of the three models predict large growth effects of policy changes. I will examine below the evidence for or against these claims, but here I will note how much these bold predictions are different from many other fields of economics, as well as from the pre-1986 growth literature. The literature on tax policy, for example, thinks that it is a big deal to identify a benefit of 0.1 percent of GDP from a major tax reform that lowers distortions. The notion that economic development of a whole society can be achieved a few stroke-of-the pen policy reforms seems simplistic in retrospect. If this is so, why haven't more countries successfully developed? Are large policy effects on growth an inevitable feature of new growth models? 
Endogenous growth and neoclassical growth with a reduction of tax rate on investment from 50 percent to zero

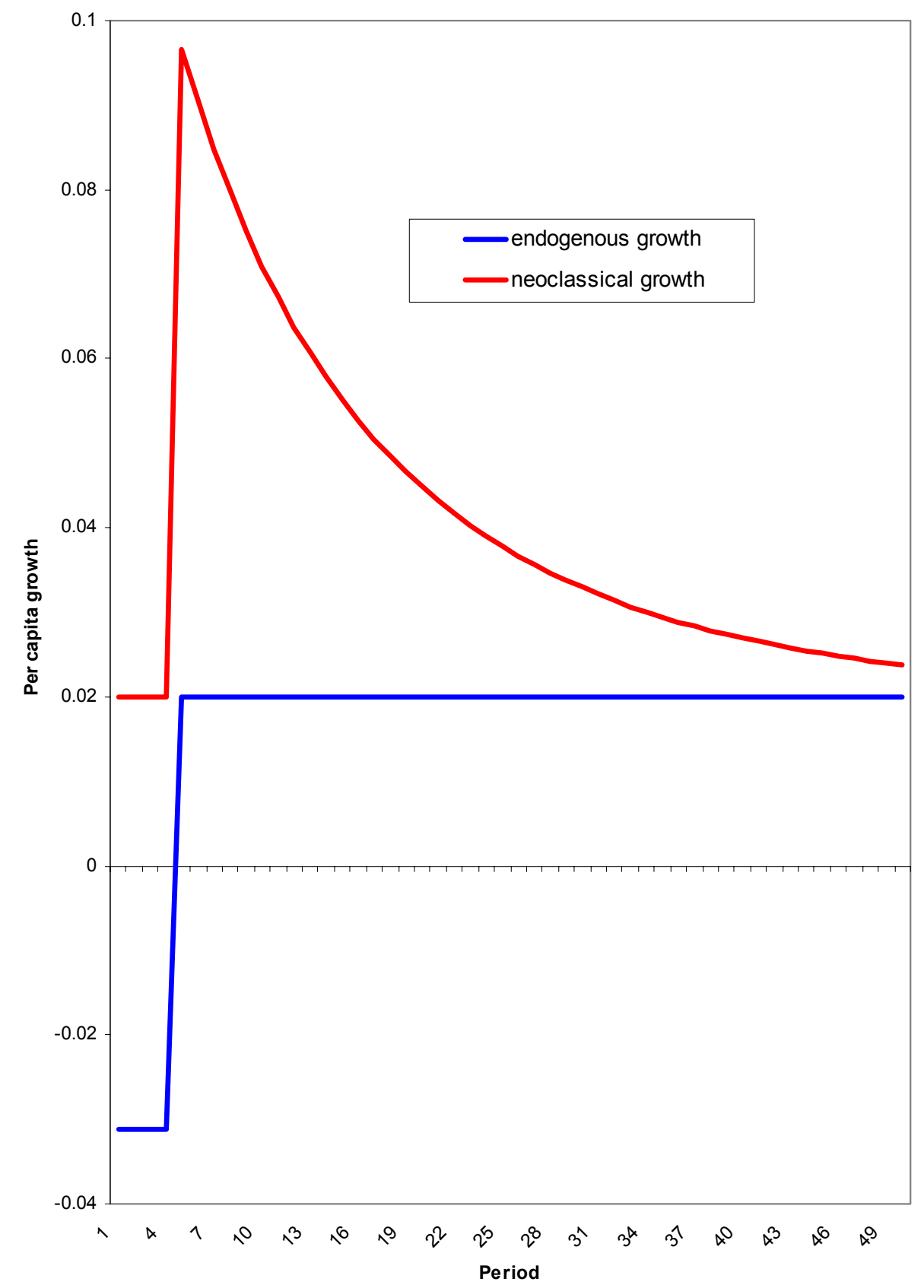




\section{Models that predict small policy effects on growth}

To begin to understand some of the factors that might mitigate the large effects of policy on growth, suppose that there output is a function of two types of capital, only one of which can be taxed. For example, suppose that the first type of capital $\left(\mathrm{K}_{1}\right)$ is formal sector capital that must be transacted on markets in the open, while the second type of capital $\left(\mathrm{K}_{2}\right)$ is informal sector capital that can be accumulated away from the prying eyes of the tax man.

$$
\begin{aligned}
& \text { (13) } Y=A\left(\alpha K_{1}^{\gamma}+(1-\alpha) K_{2}^{\gamma}\right)^{\frac{1}{\gamma}} \\
& \text { (14) } \mathrm{C}=\mathrm{Y}-(1+\tau) \mathrm{I}_{1}-\mathrm{I}_{2} \\
& \text { (15) } \dot{K}_{1}=I_{1}-\delta K_{1} \\
& \text { (16) } \dot{K}_{2}=I_{2}-\delta K_{2} \\
& \text { (17) } \frac{A \alpha\left[\alpha+(1-\alpha)\left(\frac{K_{2}}{K_{1}}\right)^{\gamma}\right]^{\frac{1-\gamma}{\gamma}}-\frac{1+\tau}{\sigma}-\rho}{\sigma}
\end{aligned}
$$

If these two capital goods are close to perfect substitutes, then the effects of taxes on growth go towards zero. Figure 3 shows the relationship between growth and tax rates at extreme values of $\gamma$. With $\gamma$ close to 1 (close to perfect substitutability), there is only a minor effect of taxes and it is bounded from below no matter how high the tax rate. This is because with the elasticity of substitution greater than one, formal sector capital is not essential to production. The worst that high tax rates can do is drive formal capital use down to zero (which has only a small effect if the capital goods are close to perfect substitutes). After that, increases in tax rates have no further effect (explaining the flat segment of the curve in figure 3). The effects of tax rates on growth continue to be strong if the elasticity of substitution between the two goods is less than one (the gamma=-1 line in Figure 3). 
Figure 3: Growth rates with different assumptions about elasticity of substitution between capital good types

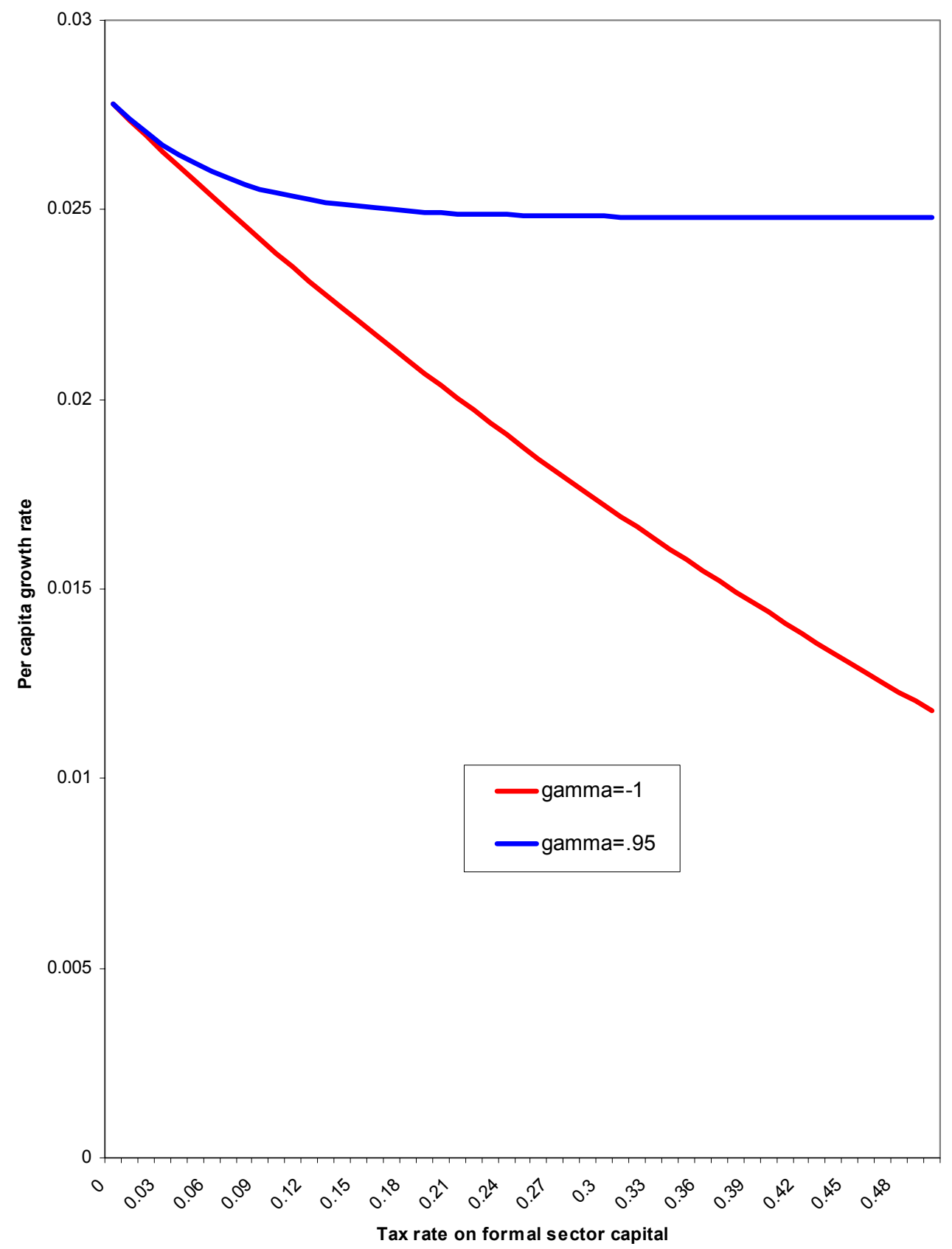


The other parameter that plays an important role in how damaging are tax rates is the share $(\alpha)$ of formal sector capital (or more specifically, the share of the capital that is actually subject to taxation). Figure 4 shows how different are the effects of taxing investment in this factor when its share $(\alpha)$ is 0.1 compared to when its share is 0.8 (assuming an elasticity of substitution of unity). Of course, lowering the share of taxable capital would also limit the power of taxation in the neoclassical model. 
Figure 4: Tax rates and growth with different shares of taxable capital

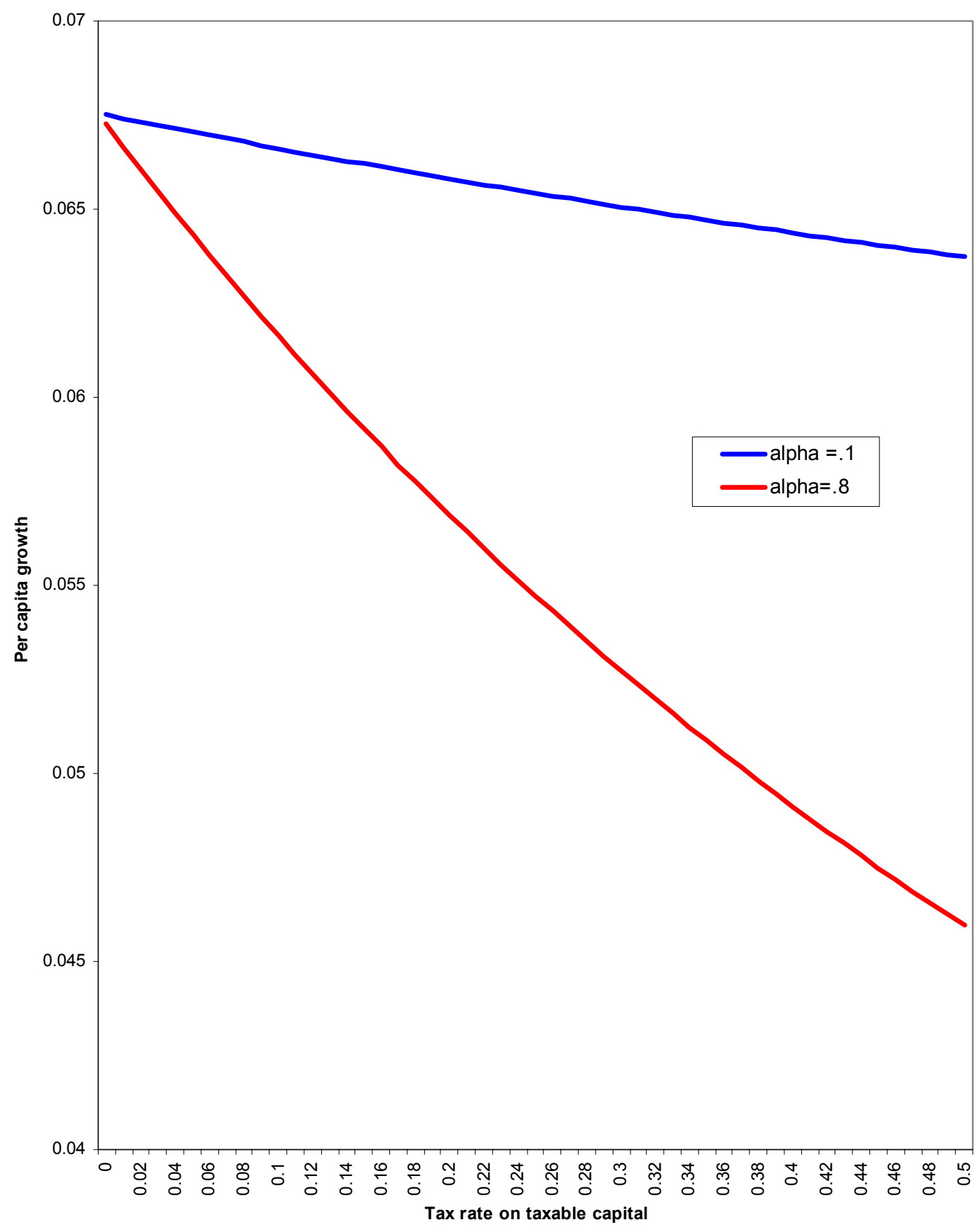


Another factor that mitigates the effects of policies on growth is that many policies distort relative prices amongst different sectors or different types of goods, rather than penalizing all capital goods. With a distortion of relative prices, some capital goods are more expensive but others are cheaper. For example, with a black market premium on foreign exchange, those who receive licenses to import goods at the official exchange rate receive a subsidy, while those who must pay the black market rate for inputs pay an implicit tax. ${ }^{7}$ Unanticipated high inflation is a tax on creditors but a subsidy to debtors. An overvalued real exchange rate penalizes producers of tradeables but subsidizes producers of nontradeables. Trade protection taxes imports but subsidizes production for the domestic market. The rate of subsidy is clearly related to the rate of taxation. One way to pin it down is to specify that the revenues from the tax on the first type of capital must just cover the subsidy expenditures on the second type of capital.

Here are the equations I have in mind. I revert to Cobb-Douglas for simplicity:

(18) $Y=A K_{1}^{\alpha} K_{2}^{1-\alpha}$

(19) $\mathrm{C}=\mathrm{Y}-(1+\tau) \mathrm{I}_{1}-(1-\mathrm{s}) \mathrm{I}_{2}$

(15) and (16) still represent the capital accumulation equations, and the consumer-producer maximizes (3) taking $\tau$ and $\mathrm{s}$ as given. Ex-post, the government must balance its budget so: (20) $\tau \mathrm{I}_{1}=\mathrm{sI}_{2}$

Because of the neat properties of Cobb-Douglas, the solution of the optimal capital ratio as a function of the subsidy rate (after taking into account the fiscal relationship (20) between tax rates and subsidy rates) is very simple:

(21) $\frac{K_{2}}{K_{1}}=\frac{1-\alpha}{\alpha-s}$

The growth rate will display offsetting effects of the subsidy-cum-tax rate - on the one hand, it distorts the allocation of capital away from $\mathrm{K}_{1}$ to $\mathrm{K}_{2}$, lowering the pre-subsidy marginal product of $\mathrm{K}_{2}$, while on the other hand, it of course subsidizes the rate of return to $\mathrm{K}_{2}$.

\footnotetext{
${ }^{7}$ If black markets function efficiently, the opportunity cost of inputs is their black market value even for those who receive them at the subsidized price. However, the recipient of inputs at the official exchange rate still receives a subsidy per unit of input use.
} 
(22) $\frac{\dot{C}}{C}=\frac{\frac{A(1-\alpha)\left(\frac{\alpha-s}{1-\alpha}\right)^{\alpha}}{1-s}-\delta-\rho}{\sigma}$

One can show that if (20) (the balanced budget requirement) is imposed, it is impossible for this kind of tax-cum-subsidy scheme to raise the rate of growth. ${ }^{8}$ The tax-cum-subsidy will imply an efficiency loss from the distortion of resource allocation, and this efficiency loss will have a negative growth effect if all types of capital can be accumulated. However, the relationship between the distortion and the growth rate is highly nonlinear. As is well known in the literature on relative price distortions, the cost of the distortion increases more than proportionately with the size of the distortion. ${ }^{9}$ In the traditional literature on "Harberger triangles", this was an output loss. In an endogenous growth model where all inputs can be accumulated, the distortion between relative prices of the inputs induces a reduction in growth. A small distortion introduces only a small wedge in between marginal products of the two inputs and does not cause a huge growth loss. Eventually, however, the distortion forces far too much accumulation of one type of capital relative to the other, severely lowering the marginal product of the excessive capital good due to diminishing returns. An increasing rate of subsidy also requires a more than one for one increase in the tax rate, as the tax base is shrinking with increased taxes while the capital goods being subsidized are increasing. The nonlinear relationship is shown in Figure 5. Note that distortions do not have much effect on growth at all up to subsidy rates of about .2 and then have increasingly catastrophic consequences after about .4

\footnotetext{
${ }^{8}$ This applies to CES production functions more generally (see Easterly 1993 for a proof).

${ }^{9}$ One recent growth model emphasizing this nonlinearity is Gylfason 1999, where the cost "e" of a distortion "c" is amusingly expressed as $\mathrm{e}=\mathrm{mc}^{2}$.
} 
Figure 5: growth rate and subsidy rate financed by taxes

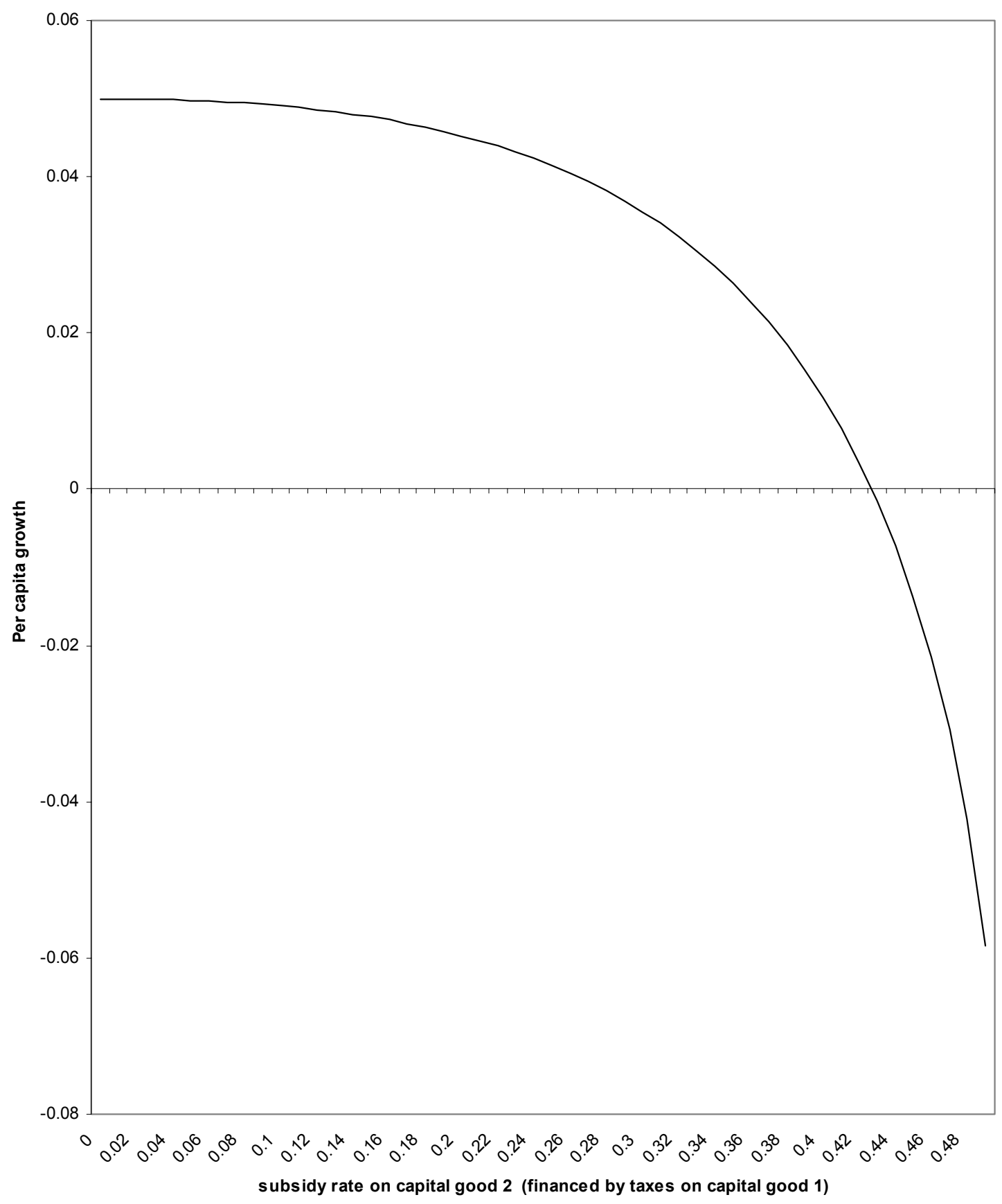


There are other factors that mitigate the effects of policy on growth that I do not explicitly model here. One is policy uncertainty. The announcement of a new policy may not be credible, perhaps because high political opposition to it may imply a high probability of subsequent reversal. Many developing countries have a history of frequent reversals of incipient policy reforms, which makes any future reform less believable. For example, Argentina has been a chronic high inflation country for nearly half a century. Frequent stabilization attempts have subsequently come unwound; the fiasco of the Convertibility Plan in 2001 is only the latest example. In terms of the model above, the certainty equivalent of the after-tax return on capital may not increase much even after an announcement that taxes will be cut.

There is also the possibility that policies whose main purpose was to create rents for political patronage will be replaced with other policies that create new rents. For example, if the black market premium is abolished, the holders of import licenses at the official exchange rate may seek new sources of income (for example, appointment as customs inspectors, where they can take bribes). There may be a law of conservation of political rents, akin to the second law of thermodynamics, if the factors inducing political rent seeking do not change.

Poor countries may be so close to subsistence consumption that they may not be able to take advantage of policy changes. Rebelo 1994 and Easterly 1994 show intertemporal utility functions with Stone-Geary preferences, in which consumers derive utility from consumption only above a certain floor of subsistence. This model predicts a very low intertemporal elasticity of substitution at levels of consumption close to subsistence. Intuitively, consumers close to subsistence have a limited ability to postpone consumption in order to take advantage of higher returns to saving. This model predicts a slow acceleration of growth even after a favorable policy change, as consumption must first rise well above subsistence.

Most importantly, policies may be offset or reinforced by more important factors that affect the growth and income. Achieving high output returns from a given set of inputs involves an incredibly complex set of institutions (such as enforcement of contracts and property rights), social norms, efficient sorting and matching of people and other inputs, advanced technological knowledge, full information on both sides of all transactions, low transaction costs, resolution of principal-agent problems, positive non-zero-sum game theoretic interactions among agents, resolution of public good problems, and so on. The development of institutions and social and 
political structures that address these issues successfully (from the standpoint of material production) is probably a long historical process.

The above models have a pale shadow of all this complexity in the parameter A. Note that the lower is A, the lower is the derivative of growth (or income in the neoclassical model) with respect to the policy parameter $\tau$. Many authors have argued that differences in A explain a large part of income differences between countries (Hall and Jones 1998, Klenow and Rodriguez-Clare 1997a,b, Easterly and Levine 2001). If a poor country is poor because of low A, then a change in policies may not do much to raise income or growth. Exogenous variation in A may also affect the political economy of policy - a high A country would be less likely to tolerate the costs of destructive policies, while bad policy may be tolerated in a low A country because it may not make much difference. Of course policy itself could influence A. However, if A really depends on all the complexities listed above, then the kind of macroeconomic policies I am considering in this paper may not have much effect on A.

Empirics

The literature tracing effects of economic policies on growth is abundant. I do not attempt to summarize it here, noting the summaries in Sala-i-Martin (2000), Temple (1997), Kenny 2001, and Easterly and Levine (2001). Some authors focus on openness to international trade (Frankel and Romer, 1999), others on fiscal policy (Easterly and Rebelo, 1993), others on financial development (Levine, Loayza, and Beck, 2000), and others on macroeconomic policies (Fischer 1993). Dollar (1992) stressed a measure of real exchange rate overvaluation as a proxy for outward orientation and thus a determinant of growth. These papers have at least one common feature: they all find that some indicator of national policy is strongly linked with economic growth, which confirms the argument made by Levine and Renelt (1992) - even though Levine and Renelt found that it was difficult to discern WHICH policy matters for growth. The list of national economic policies that have received most extensive attention are fiscal policy, inflation, black market premiums on foreign exchange, financial repression vs. financial development, real overvaluation of the exchange rate, and openness to trade. The recommendation that countries pursue good policies on all these dimensions was labeled by Williamson (1985) as the "Washington Consensus."

I distinguish policies from "institutions", which have their own rich literature (see 
Acemoglu et al. 2001, 2002, La Porta et al 1999, 1998, Kaufmann et al. 1999, Levine ).

Institutions reflect deep-seated social arrangements like property rights, rule of law, legal traditions, trust between individuals, democratic accountability of governments, and human rights. Although governments can slowly reform institutions, they are not "stroke of the pen" reforms like changes in the macroeconomic policies listed above. I will consider at the end the relative role of policies and institutions in development.

\section{Some empirical caveats}

There are several things to note about the evidence on policies and growth before proceeding to new empirical analysis. The first is that the literature has devoted much effort to the most obvious candidate for a policy that influences growth - tax rates. Yet the literature has generally failed to find a link between income or output taxes and economic growth (Easterly and Rebelo 1993, Slemrod 1996). Nor are we likely to find that taxes have level effects, as rich countries have higher tax rates than poor countries. The outcome of natural experiments like the large tax increases in the US associated with the introduction of the income tax and the World Wars does not indicate income or level effects of taxes (Rebelo and Stokey 1995). Hence, the most obvious policy variable affecting growth is out of the running from the start.

Second, national economic policies are generally measured over the period 1960-2000, which is when data is available. This is also the period in which countries had independent governments making policy, as opposed to colonial regimes (on which we do not have data). Hence, if policies have an effect on the level or growth rate of income, this would have to show up in the period 1960-2000. However, history did not begin with a clean slate in 1960. The correlation of per capita income in 1960 with per capita income in 1999 is .87 . Most of countries' relative performance is explained by the point they had already reached by 1960. It follows that the role of post-1960 policies in determining development outcomes can only be limited. A view of economic development that puts all the weight on the 1960-2000 period is ahistorical, assuming away the complex histories of civilizations, conquests, and colonies.

Third, there is the general fact that developing countries had higher growth rates in the period 1960-79 than in the period 1980-2000. Yet most of the "Washington Consensus" policies were adopted only after 1980. In the pre-1980 days, there was much more of an emphasis on state intervention and import-substituting industrialization, as opposed to the free trade, "get the 
prices right" approach after 1980. This big fact does not augur well for a strong positive effect of "good policies" on growth, although the growth slowdown after 1980 could have other causes.

Easterly 2001 showed the divergence between improving growth predicted by policies and actual growth outcomes across the 60s, 70s, 80s, and 90s (see figure).

Figure 1a: Predicted vs actual per capita growth for developing countries (assuming constant intercept across decades)

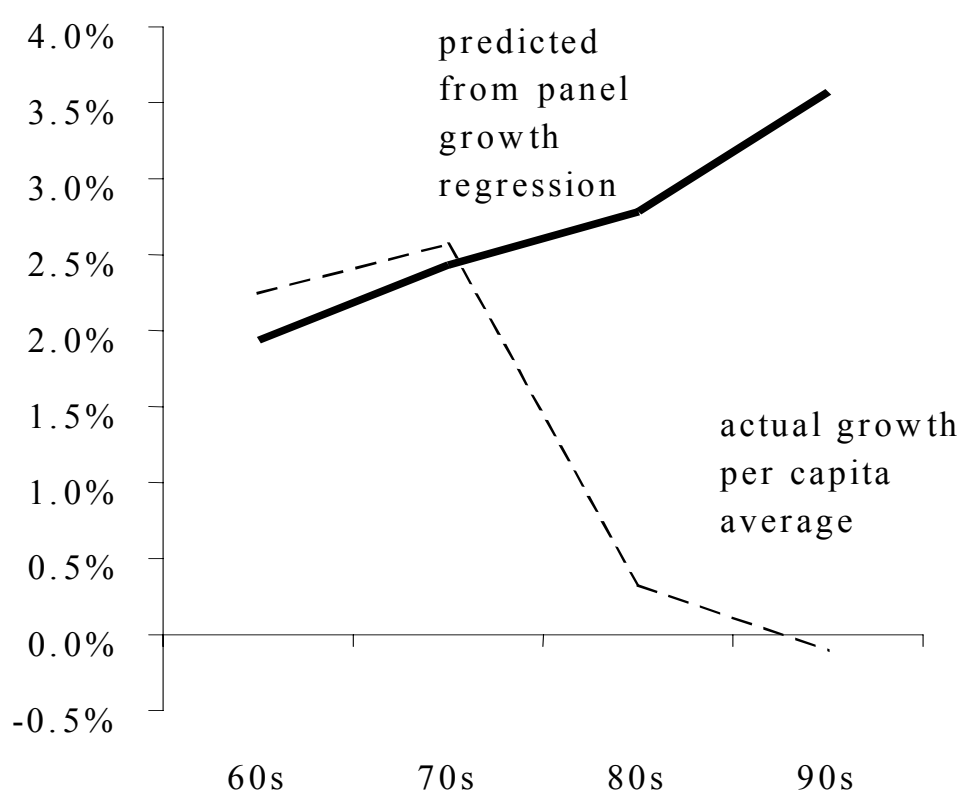


Fourth, there are many income differences within nations - between the sexes, between ethnic groups, and between regions - that cannot be explained by national economic policies. Easterly and Levine show that there are four ethnic-geographic clusters of counties with poverty rates above 35 percent in the U.S: (1) Counties in the West that have large proportions ( $>35 \%)$ of native Americans; (2) Counties along the Mexican border that have large proportions (>35\%) of Hispanics; (3) Counties adjacent to the lower Mississippi River in Arkansas, Mississippi, and Louisiana and in the "black belt" of Alabama, all of which have large proportions of blacks (>35\%); (4) Virtually all-white counties in the mountains of eastern Kentucky. The county data did not pick up the well-known inner-city form of poverty, mainly among blacks, because counties that include inner cities also include rich suburbs. An inner city zip code in DC, College Heights in Anacostia, has only one-fifth of the income of a rich zip code (20816) in Bethesda MD. This has an ethnic dimension again since College Heights is 96 percent black and the rich zip code in Bethesda is 96 percent white. The purely ethnic differentials in the US are well known. Blacks earn 41 percent less than whites; Native Americans earn 36 percent less; Hispanics earn 31 percent less; Asians earn 16 percent more.10 There are also more subtle ethnic earnings differentials. Third-generation immigrants with Austrian grandparents had 20 percent higher wages in 1980 than third-generation immigrants with Belgian grandparents (Borjas 1992). Among Native Americans, the Iroquois earn almost twice the median household income of the Sioux. Other ethnic differentials appear by religion. Episcopalians earn 31\% more income than Methodists (Kosmin and Lachman, 1993, p. 260) Twenty-three percent of the Forbes 400 richest Americans are Jewish, although only two percent of the US population is Jewish (Lipset 1997).11

Poverty areas exist in many countries: northeast Brazil, southern Italy, Chiapas in Mexico, Balochistan in Pakistan, and the Atlantic Provinces in Canada. Bouillon, Legovini and

\footnotetext{
${ }^{10}$ Tables 52 and 724, 1995 Statistical Abstract of US.

${ }^{11}$ Ethnic differentials are also common in other countries. The ethnic dimension of rich trading elites is wellknown: the Lebanese in West Africa, the Indians in East Africa, and the overseas Chinese in Southeast Asia. Virtually every country has its own ethnographic group noted for their success. For example, in The Gambia a tiny indigenous ethnic group called the Serahule is reported to dominate business out of all proportion to their numbers - they are often called "Gambian Jews." In Zaire, Kasaians have been dominant in managerial and technical jobs since the days of colonial rule -- they are often called "the Jews of Zaire" (New York Times, 9/18/1996).
} 
Lustig 1999 find that there is a negative Chiapas effect in Mexican household income data, and that this effect has gotten worse over time. Households in the poor region of Tangail/Jamalpur in Bangladesh earned less than identical households in the better off region of Dhaka (Ravallion and Wodon 1998). Ravallion and Jalan (1996) and Jalan and Ravallion (1997) likewise found that households in poor counties in southwest China earned less than households with identical human capital and other characteristics in rich Guangdong Province.

In Latin America, the main ethnic divide is between indigenous and non-indigenous populations and between white, mestizo, and black populations. In Mexico, 80.6 percent of the indigenous population is below the poverty line, while only 18 percent of the non-indigenous population is below the poverty line. 12 But even within indigenous groups in Latin America, there are ethnic differentials. There are 4 main language groups among Guatemala's indigenous population. Patrinos 1997 shows that the Quiche-speaking indigenous groups in Guatemala earn 22 percent less on average than Kekchi-speaking groups.

In Africa, there are widespread anecdotes about income differentials between ethnic groups, but little hard data. The one exception is South Africa. South African whites have 9.5 times the income of blacks. More surprisingly, among all-black traditional authorities (an administrative unit something like a village) in the state of KwaZulu-Natal, the ratio of the richest traditional authority to the poorest is 54 (Klitgaard and Fitschen 1997). While not ruling out national policy effects, these differences also highlight the importance of factors that do not operate at the national level.

Fifth, the role of policies in explaining post-1960 growth is bounded once we realize that policy variables are much more stable over time than are growth rates. ${ }^{13}$ Figure 6 shows the correlation coefficient across successive 5-year periods between different kinds of policies and growth. As noted in the theoretical section, stability of policies over time and instability of growth rates is inconsistent with the AK model. It could be consistent with either the neoclassical model or the increasing returns growth model, assuming that policies are close to the steady state or critical point, respectively. Note that the non-persistence of growth rates and the high persistence of income levels is consistent, since persistent differences in growth rates

12 Source: Psacharopoulos and Patrinos 1994, p. 6. 
would be required to scramble the income rankings from 1960 to 1999.

Figure 6: Persistence over time of policies and growth

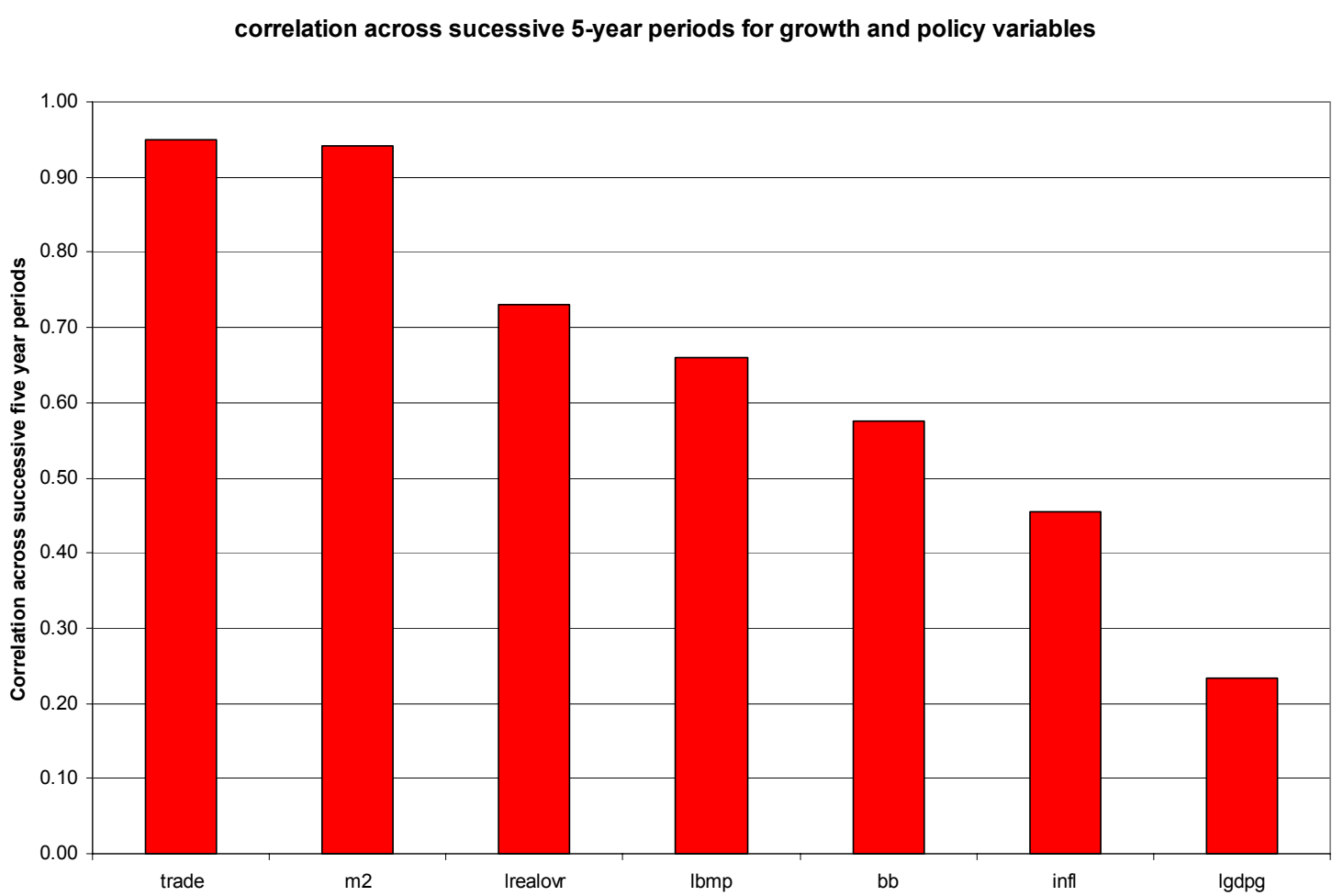

\section{New empirical work}

Here I synthesize past results by running new regressions on an updated dataset for the years 1960-2000, using a panel of five year averages. Following the literature, I concentrate on the most common measures of macroeconomic policies, price distortions, financial development, and trade openness. My variables are listed in Table 1. Table 2 shows the variables' summary statistics.

\footnotetext{
${ }^{13}$ This was pointed out by Easterly, Kremer, Pritchett, and Summers 1993.
} 
Table 1: Variables used in analysis

\begin{tabular}{|c|c|c|}
\hline Variable name & Definition & Source \\
\hline & Log per capita growth & World \\
\hline LGDPG & rate & $\begin{array}{l}\text { Bank } 2002 \\
\text { World }\end{array}$ \\
\hline INFL & Log (1+inflation rate) & Bank 2002 \\
\hline & Government budget & World \\
\hline $\mathrm{BB}$ & balance/GDP & $\begin{array}{l}\text { Bank } 2002 \\
\text { World }\end{array}$ \\
\hline M2 & $\begin{array}{l}\text { M2/GDP } \\
\text { Log (Overvaluation } \\
\text { index/100) (above }\end{array}$ & Bank 2002 \\
\hline & zero indicates & World \\
\hline LREALOVR & overvaluation) & Bank 2002 \\
\hline & $\begin{array}{l}\text { Log }(1+\text { black market } \\
\text { premium on foreign }\end{array}$ & World \\
\hline LBMP & exchange) & Bank 2002 \\
\hline & (Exports + & World \\
\hline TRADE & Imports)/GDP & Bank 2002 \\
\hline & Government & World \\
\hline GOVC & consumption/GDP & Bank 2002 \\
\hline & Private sector & World \\
\hline PRIV & credit/Total Credit & Bank 2002 \\
\hline & & Summers- \\
\hline & & $\begin{array}{l}\text { Heston } \\
1991\end{array}$ \\
\hline & & $\begin{array}{l}\text { updated } \\
\text { using }\end{array}$ \\
\hline LNEWGDP & Log of per capita GDP & LGDPG \\
\hline & Log of total schooling & Barro-Lee \\
\hline LTYR & years & 2000 \\
\hline
\end{tabular}


Table 2: Summary Statistics

Std.

$\begin{array}{lrrrrr}\text { Variable } & \text { Obs } & \text { Mean } & \text { Dev. } & \text { Min } & \text { Max } \\ \text { infl } & 967 & 0.159 & 0.325 & -0.569 & 3.447 \\ \text { lnewgdp } & 921 & 8.107 & 1.040 & 5.775 & 10.445 \\ \text { lgdpg } & 1306 & 0.017 & 0.051 & -0.736 & 0.276 \\ \text { govc } & 1241 & 15.790 & 6.700 & 3.915 & 58.310 \\ \text { bb } & 958 & -0.037 & 0.054 & -0.417 & 0.391 \\ \text { m2 } & 1064 & 0.349 & 0.253 & 0.009 & 1.929 \\ \text { priv } & 916 & 0.355 & 0.329 & 0.000 & 2.085 \\ \text { lrealovr } & 609 & 0.060 & 0.387 & -1.206 & 1.612 \\ \text { lbmp } & 1024 & 0.254 & 0.558 & -1.058 & 8.311 \\ \text { trade } & 1270 & 0.702 & 0.454 & 0.018 & 3.803 \\ \text { ltyr } & 832 & 1.277 & 0.820 & -2.453 & 2.476\end{array}$

Table 3 shows the correlation coefficients between these variables and growth as well as between distinct policies. All of the bivariate correlations of policy variables with per capita growth are statistically significant at the 5 percent level. Most of the pairwise correlations between policy variables are also statistically significant, indicating the problem of collinearity that has plagued the literature. Bad policies tend to go together along a number of dimensions. M2 and PRIV have such a high correlation that it is clear they are measuring the same thing the overall level of financial development.

LGDPG INFL BB LREALOVR LBMP M2 TRADE PRIV GOVC

$\begin{array}{lrrrrrrrrr}\text { LGDPG } & 1.000 & -0.376 & 0.155 & -0.213 & -0.321 & 0.097 & 0.101 & 0.130 & -0.130 \\ \text { INFL } & -0.376 & 1.000 & -0.201 & 0.078 & 0.287 & -0.193 & -0.078 & -0.212 & 0.031 \\ \text { BB } & 0.155 & -0.201 & 1.000 & -0.141 & -0.144 & -0.010 & 0.094 & 0.110 & -0.231 \\ \text { LREALOVR } & -0.213 & 0.078 & -0.141 & 1.000 & 0.247 & -0.083 & -0.056 & -0.028 & 0.228\end{array}$




$\begin{array}{lrrrrrrrrr}\text { LBMP } & -0.321 & 0.287 & -0.144 & 0.247 & 1.000 & -0.073 & -0.178 & -0.241 & -0.036 \\ \text { M2 } & 0.097 & -0.193 & -0.010 & -0.083 & -0.073 & 1.000 & 0.375 & 0.716 & 0.246 \\ \text { TRADE } & 0.101 & -0.078 & 0.094 & -0.056 & -0.178 & 0.375 & 1.000 & 0.161 & 0.276 \\ \text { PRIV } & 0.130 & -0.212 & 0.110 & -0.028 & -0.241 & 0.716 & 0.161 & 1.000 & 0.215 \\ \text { GOVC } & -0.130 & 0.031 & -0.231 & 0.228 & -0.036 & 0.246 & 0.276 & 0.215 & 1.000\end{array}$

I now concentrate on a core set of six variables (chosen after a little bit of the usual data mining) that seem to capture distinct dimensions of policy: inflation, budget balance, real overvaluation, black market premium, financial depth, and trade openness. Initially, I will test the AK model's prediction that these policies will have growth rather than level effects, so I do not control for initial income (I will check this later on). I will use a variety of specifications and econometric methods to assess how robust are the statistical associations between policies and growth. In table 4, I regress growth on all six policy variables, and then try dropping one at a time. In the base specification, four of the six policies are statistically significant at the 5 percent level, with trade openness just barely falling short. When I experiment with dropping one variable at a time, all of the six policy variables are significant at one time or another. The coefficients on the policy variables are fairly stable across different permutations of the variables. ${ }^{14}$

Table 4: Regressions of per capita growth on basic set of 6 policy variables Dependent variable: Lgdpg (log per capita growth, five year averages, 1960-2000)
INFL
$-0.018$
$-0.02$
$-0.02$
$-0.034$
$-0.021$
$-0.018$
$(2.61)^{*}$
$(3.13)^{*}$
$(2.87)^{*}$
$(6.27)^{*}$
$(3.39)^{*} \quad(2.60)^{*}$
BB
$0.092 \quad 0.114$
$0.092 \quad 0.053$
0.109
0.098
$(2.81)^{*}$
$(3.48)^{*}$
$(3.07)^{*}$
$(3.07)^{*}$
$(3.37)^{*}$
$(2.92)^{*}$
M2
$\begin{array}{lll}0.01 & 0.013 & 0.014\end{array}$
0.017
$0.013 \quad 0.015$

\footnotetext{
${ }^{14}$ The other policy variables that I tested: government consumption and private sector credit, were not significant when entered in addition to these variables (or substituting government consumption for budget deficits and private sector credit for M2).
} 


\begin{tabular}{|c|c|c|c|c|c|c|c|}
\hline & 1.37 & 1.92 & $(2.04)^{*}$ & & $(2.26)^{*}$ & $(1.99)^{*}$ & $(2.15)^{*}$ \\
\hline \multirow[t]{3}{*}{ LREALOVR } & -0.014 & -0.013 & -0.016 & -0.013 & & -0.015 & -0.013 \\
\hline & $(2.97)^{*}$ & $(2.98)^{*}$ & $(3.74)^{*}$ & $(2.83)^{*}$ & & $(3.56)^{*}$ & $(2.88)^{*}$ \\
\hline & $*$ & $*$ & $*$ & $*$ & & $*$ & * \\
\hline \multirow[t]{3}{*}{ LBMP } & -0.012 & -0.017 & -0.01 & -0.014 & -0.005 & & -0.013 \\
\hline & & $(3.43)^{*}$ & & $(2.73)^{*}$ & & & $(2.60)^{*}$ \\
\hline & $(2.33)^{*}$ & $*$ & $(2.06)^{*}$ & $*$ & -0.93 & & $*$ \\
\hline \multirow[t]{3}{*}{ TRADE } & 0.01 & 0.011 & 0.011 & 0.012 & 0.001 & 0.008 & \\
\hline & & & & $(2.62)^{*}$ & & & \\
\hline & 1.92 & $(2.22)^{*}$ & $(2.15)^{*}$ & $*$ & 0.31 & $(2.13)^{*}$ & \\
\hline \multirow[t]{3}{*}{ Constant } & 0.016 & 0.013 & 0.01 & 0.021 & 0.019 & 0.015 & 0.021 \\
\hline & $(3.62)^{*}$ & $(3.09)^{*}$ & & $(5.67)^{*}$ & $(4.81)^{*}$ & $(3.92)^{*}$ & $(5.55)^{*}$ \\
\hline & $*$ & $*$ & $(2.33)^{*}$ & $*$ & $*$ & $*$ & $*$ \\
\hline Observations & 422 & 434 & 458 & 495 & 573 & 455 & 424 \\
\hline R-squared & 0.18 & 0.15 & 0.16 & 0.17 & 0.13 & 0.17 & 0.17 \\
\hline
\end{tabular}

Robust standard errors, significant $t$ statistics in parentheses

* significant at 5\%; ** significant at $1 \%$

Table 5 shows the effect on growth of a one standard deviation improvement in each of the policy variables on growth. If all six variables were improved at the same time, the regression suggests a 3 percentage point improvement in per capita growth. These results seem to support the assertion that policies have strong effects on per capita growth. 
Table 5: Efffect of one standard deviation

improvement in each policy variable on economic

growth

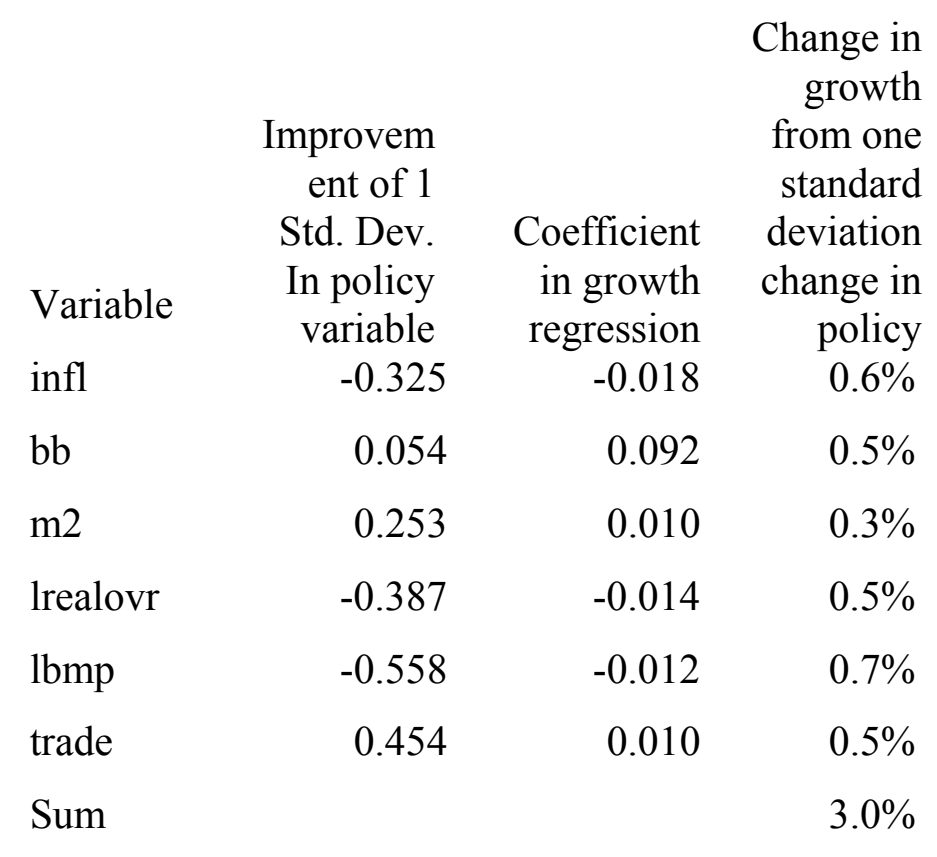

The promise of getting 3 additional percentage points of growth due to a moderate policy reform package is very seductive. However, there is something disquieting about these results upon further reflection. The one standard deviation change in the policy variables is often very large: reduction of .32 in log inflation, 5 percentage point improvement in the budget balance as a ratio to GDP, 25 percentage point increase in M2/GDP, reduction of -.39 in log real overvaluation, reduction of -.56 in log black market premium, and increase of 45 percentage points in Trade/GDP ratio. Such large changes are outside the experience of most countries with moderate inflation, budget deficits, real overvaluation, black market premiums, etc. How come the standard deviations in the sample are so large? Histograms of the sample distribution of policies gives some insight into this question. Except for the real overvaluation index, all of the policy variables are highly skewed, with most of the sample concentrated at low values and a few very extreme observations. The outlying observations of inflation, budget deficits, and black market premium are realizations of extreme "bad policies". The outlying observations of trade/GDP and 
M2/GDP are realizations of extreme "good policies." It is econometric commonsense that extreme observations can be very influential in determining statistical significance of right hand side variables. How do the above regressions do over more moderate ranges of policy variables?

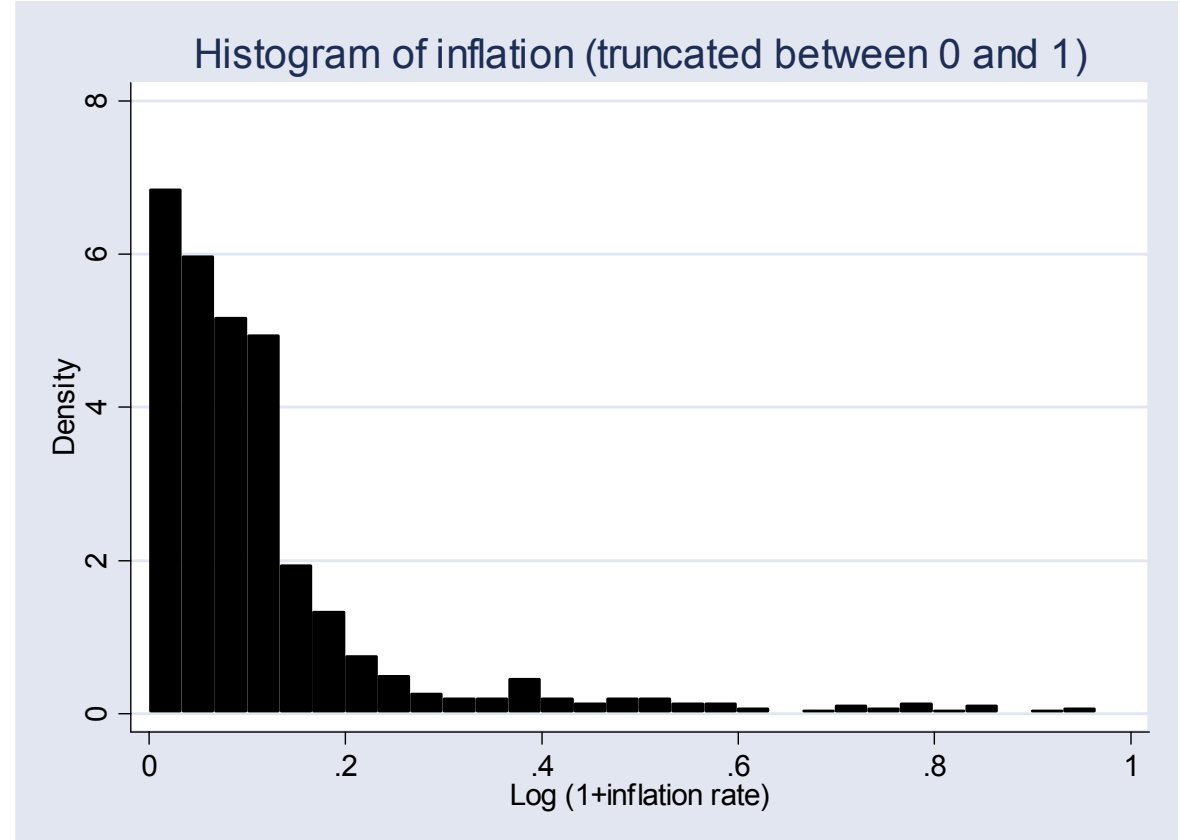

Histogram of real ovevaluation (truncated between -.1 and 1)

D. Dollar Index of Real Exchange Rate ( $>100=$ PPP overvaluation)

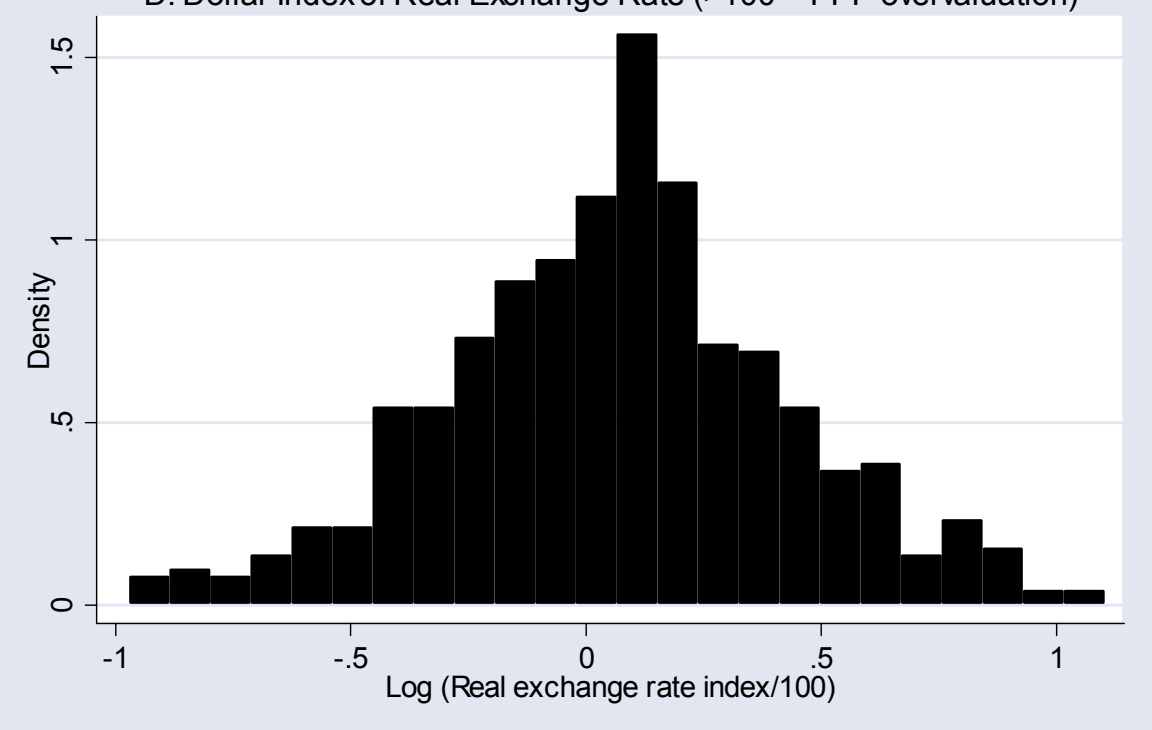



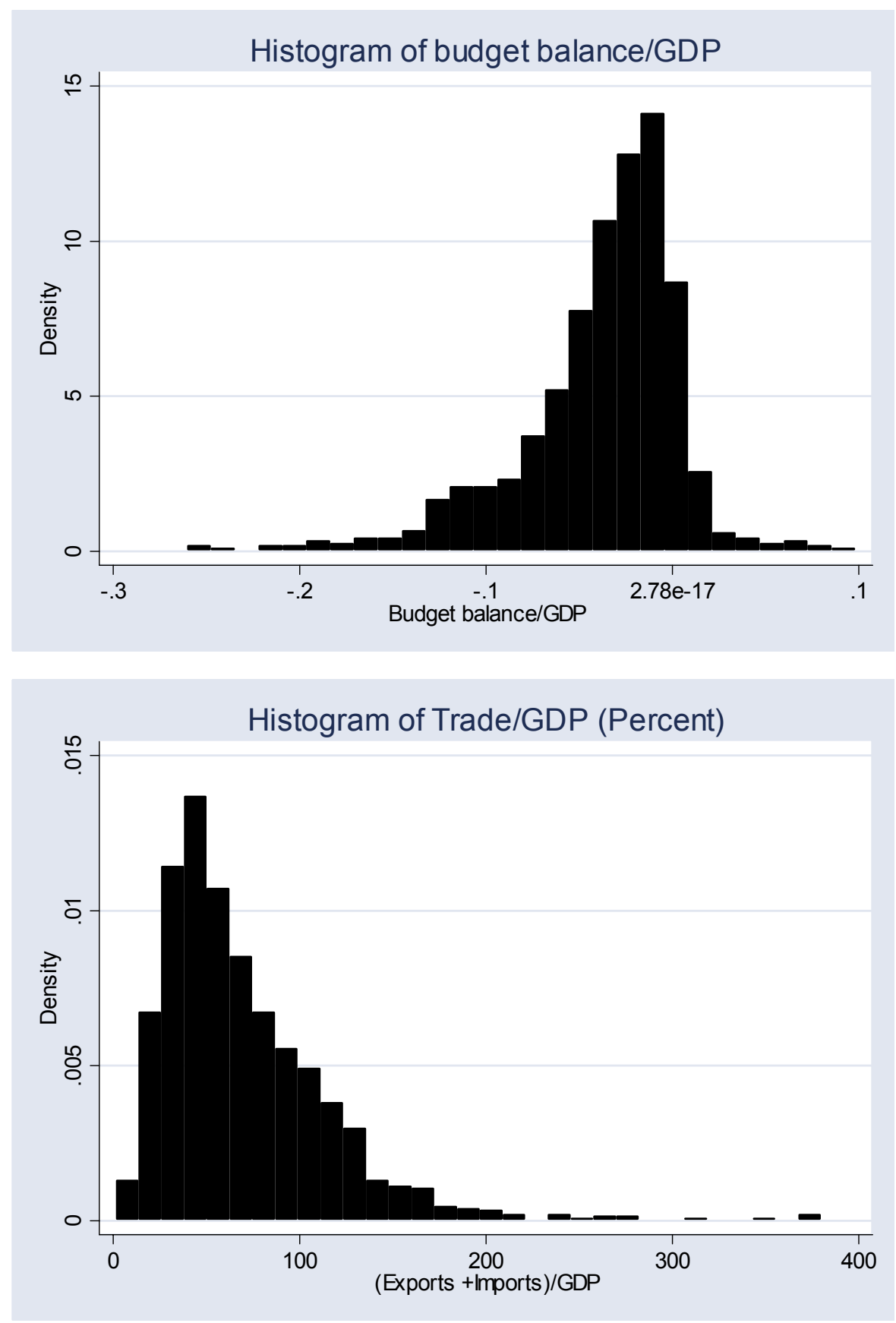


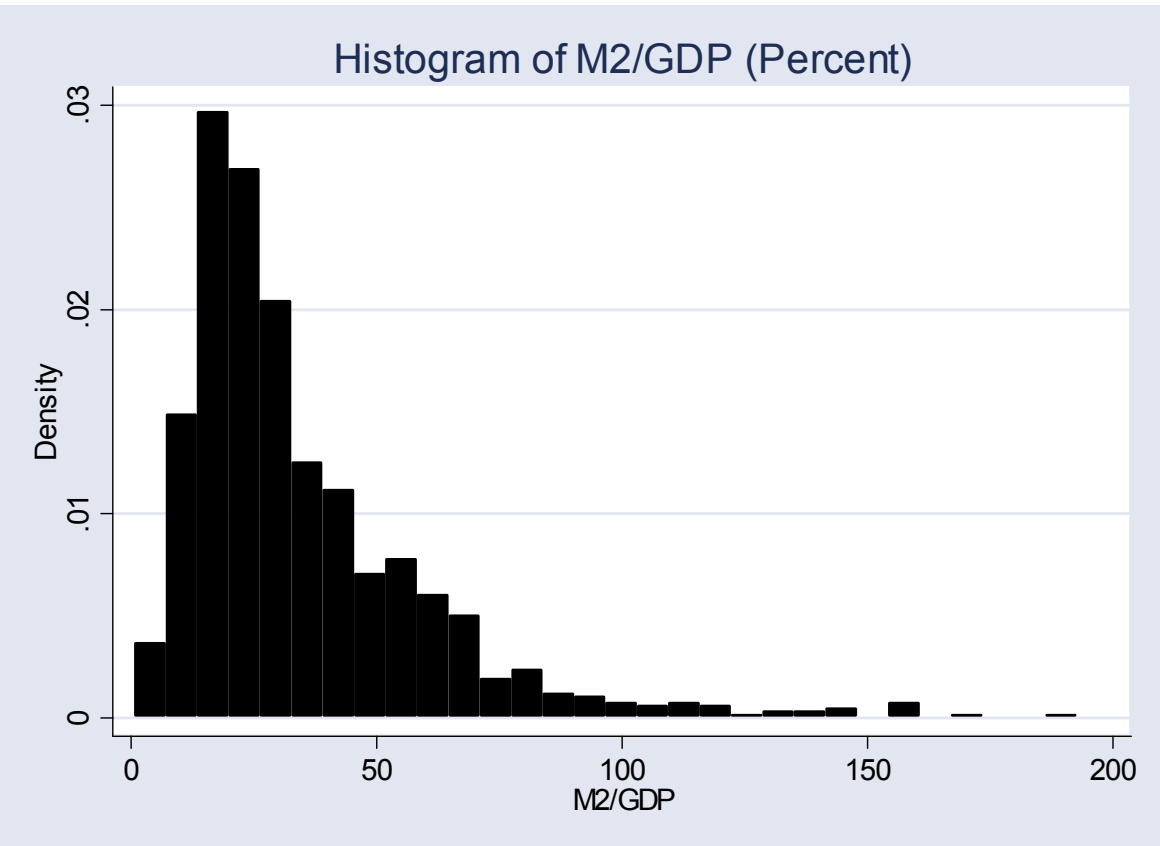

Table 6 shows the effect of restricting the sample to observations where all six policy variables lie in the range of "moderate" policies. Moderate is defined rather arbitrarily by eye-balling the histograms above to determine where are the cutoffs containing the bulk of the sample. Nevertheless, the cutoffs would fit a common-sense description of "extremes": inflation and black market premiums more than .3 in $\log$ terms ( 35 percent), real overvaluation more than .5 (68 percent), budget deficits greater than 12 percent of GDP, M2 to GDP ratios of more than 100 percent, and Trade to GDP ratios of more than 120 percent. The results of excluding any observation where any of the six policy variables are "extreme" is striking: all six policy variables become insignificant, and the F-statistic for their joint effect also falls short of significance. This is not to dismiss the evidence for policy effects on growth (reducing the range of the right hand side variables would be expected to diminish statistical significance). These extremes are far from irrelevant, as observation in which at least one of the six policies was "extreme" account for more than half the sample. However, these results highlight the dependence of the policy and growth evidence on extreme observations of the policy variables. The significance of extreme values and the insignificance of moderate ones is also consistent with the prediction of the theoretical model on the nonlinear effects of tax-cum-subsidy policies on economic growth. There is also the possible endogeneity of these extreme policies, which 
may reflect general institutional or political chaos. The results suggest that countries not undergoing extreme values of these variables do not have strong reasons to expect growth effects of moderate changes in policies. ${ }^{15}$

\section{Table 6: Robustness of results to restricting sample to moderate policy range \\ Dependent variable is \\ LGDPG}

\begin{tabular}{|c|c|c|}
\hline Sample & Full & $\begin{array}{l}\text { Moderat } \\
\text { e policies }\end{array}$ \\
\hline \multirow[t]{2}{*}{ INFL } & $\begin{array}{c}-0.018 \\
(2.61)^{*}\end{array}$ & -0.064 \\
\hline & $*$ & -1.23 \\
\hline \multirow[t]{2}{*}{ BB } & $\begin{array}{r}0.092 \\
(2.81)^{*}\end{array}$ & 0.018 \\
\hline & $*$ & 0.22 \\
\hline \multirow[t]{2}{*}{ M2 } & 0.01 & -0.004 \\
\hline & 1.37 & 0.27 \\
\hline \multirow[t]{2}{*}{ LREALOVR } & $\begin{array}{r}-0.014 \\
(2.97)^{*}\end{array}$ & 0.001 \\
\hline & $*$ & 0.06 \\
\hline \multirow[t]{2}{*}{ TRADE } & 0.01 & 0.01 \\
\hline & 1.92 & 1.09 \\
\hline \multirow[t]{2}{*}{ LBMP } & -0.012 & -0.038 \\
\hline & $(2.33)^{*}$ & -0.95 \\
\hline \multirow[t]{2}{*}{ Constant } & $\begin{array}{r}0.016 \\
(3.62)^{*}\end{array}$ & 0.027 \\
\hline & $*$ & $(2.52)^{*}$ \\
\hline Observations & 422 & 193 \\
\hline R-squared & 0.18 & 0.03 \\
\hline \multicolumn{3}{|c|}{$\begin{array}{l}\text { Robust } t \text { statistics in parentheses } \\
* \text { significant at } 5 \% ; * * \text { significant at } \\
1 \%\end{array}$} \\
\hline
\end{tabular}

Restrictions under moderate policies: infl between -.05 and .3, BB between .12 and $.02, \mathrm{~m} 2<1.0$, lrealovr between -.5 and .5, trade $<1.20,1 \mathrm{bmp}$ between .05 and .3

\footnotetext{
${ }^{15}$ The empirical literature on inflation has found that inflation only has a negative effect above some threshold level,
} 
These results are fairly intuitive if we think of destroying growth as a different process from creating growth. It is a lot easier to cut down a tree than to grow one. ${ }^{16}$ Countries that pursue destructive policies like high inflation, high black market premium, chronically high budget deficits and other signs of macroeconomic instability are plausible candidates to miss out on growth. However, it doesn't follow that one can create growth with relative macroeconomic stability. The policies are inherently asymmetric - a leader can sow chaos by printing money and controlling the exchange until he gets a hyperinflation and an absurd black market premium. However, the best he can do in the other direction is zero inflation and zero black market premium. The results on policies and growth may simply reflect the potential for destruction from bad policies, not the potential for fostering long run development through good policy. The next thing to test is whether initial income belongs in the growth equation, as the neoclassical model would imply. It has also been common in the literature to add initial schooling as an indicator of whether the balance between physical and human capital is far from the optimal level. Table 7 shows the results on initial income and schooling:

although there are disagreements as to where that threshold is (Bruno and Easterly 1998, Barro 1996, 1998, Sarel 1996).

${ }^{16}$ Easterly 2001 has a chapter "how governments can destroy growth." 


\section{Table 7}

\begin{tabular}{|c|c|c|c|c|}
\hline $\begin{array}{l}\text { Dependent } \\
\text { variable }\end{array}$ & Lgdpg & Lgdpg & Lgdpg & Lgdpg \\
\hline INFL & -0.018 & -0.019 & -0.02 & -0.019 \\
\hline & $(2.61)^{*}$ & $(2.67)^{*}$ & $(2.65)^{*}$ & $(2.85)^{*}$ \\
\hline & * & $*$ & & \\
\hline $\mathrm{BB}$ & 0.092 & 0.102 & 0.124 & 0.107 \\
\hline & $(2.81)^{*}$ & & $(2.65)^{*}$ & \\
\hline & $*$ & $(2.44)^{*}$ & * & $(2.57)^{*}$ \\
\hline M2 & 0.010 & 0.004 & 0.002 & 0.006 \\
\hline & 1.37 & 0.41 & 0.16 & 0.67 \\
\hline LREALOVR & -0.014 & -0.014 & -0.013 & -0.014 \\
\hline & $(2.97)^{*}$ & $(3.07)^{*}$ & & $(2.96)^{*}$ \\
\hline & $*$ & * & $(2.40)^{*}$ & $*$ \\
\hline TRADE & 0.01 & -0.01 & -0.01 & -0.011 \\
\hline & 1.92 & -1.83 & -1.63 & -1.96 \\
\hline LBMP & -0.012 & 0.01 & 0.008 & 0.009 \\
\hline & $(2.33)^{*}$ & 1.87 & 1.37 & 1.62 \\
\hline Lnewgdp & & 0.003 & -0.001 & 0.0480 \\
\hline & & 1.4 & -0.28 & 1.96 \\
\hline Ltyr & & & 0.007 & \\
\hline & & & 1.42 & \\
\hline Lnewgdp^2 & & & & -0.0030 \\
\hline & & & & -1.87 \\
\hline Constant & 0.016 & -0.004 & 0.019 & -0.187 \\
\hline & $(3.62)^{*}$ & & & \\
\hline & $*$ & -0.25 & -0.87 & -1.86 \\
\hline Observations & 422 & 411 & 359 & 411 \\
\hline R-squared & 0.18 & 0.18 & 0.19 & 0.18 \\
\hline
\end{tabular}

Robust $t$ statistics in parentheses

* significant at 5\%; ** significant at $1 \%$

Turning point for convergence

2981

The results are not very supportive of a conditional convergence result. Initial income and schooling do not enter significantly, although a nonlinear formulation of hump-shaped conditional convergence (including initial income squared) comes close to significance. ${ }^{17}$ Since there is a large literature starting with Barro 1991 and Barro and Sala I Martin 1992 that does

\footnotetext{
${ }^{17}$ Hump-shaped convergence is consistent with a neoclassical model in which there is some subsistence floor to consumption (the Stone-Geary utility function).
} 
find conditional convergence, I do not claim this result is decisive. It does show the fragility of the results on both policies and initial conditions (note that three of the policy variables become insignificant when initial income is included). I will come back to the issue of conditional convergence when I examine effects of policy on growth with dynamic panel methods.

There is another robustness check that we should perform on the policies and growth results. Following common practice in the literature, I have been doing regressions on pooled time series cross section observations. This implicitly assumes that the effects on growth of a policy change over time are the same as a policy difference between countries. It is straightforward to test this restriction by doing within and between regressions on the pooled sample. Table 8 shows the results. I also show the results of a random effects regression, which gives results similar to OLS on the pooled sample. The test of whether the random effects are orthogonal to the right hand side variables is an indirect test of the equality of the coefficients from the between and within regressions. I strongly reject the hypothesis that the random effects are orthogonal. We can see from the between and within (fixed effects) regressions that the coefficients across time and across countries are indeed very different. Inflation is not significant in the between regression but strongly significant in the within regression. ${ }^{18}$ The budget balance is the reverse: strongly significant in the between regression but not in the fixed effects regression. The weak result that I found on M2/GDP in the pooled regression turns out to be because the between and within effects tend to cancel out: M2/GDP is strongly positively correlated with growth in the between regression and negatively correlated with growth in the within regressions. Real overvaluation and trade also show different results in the two different panel methods (real overvaluation is significant between countries and insignificant within countries, while trade is the reverse). This instability of growth effects is inconsistent with a simple AK view of growth with instantaneous transitional dynamics. It is also possible that five year averages are not long enough to wipe out cyclical fluctuations. The negative correlation between M2/GDP and growth could be seen as a cyclical pattern such as a loosening of monetary policy during recessions and tightening during booms. Likewise the correlation of trade/GDP with growth could indicate that international trade is pro-cyclical, as opposed to

\footnotetext{
${ }^{18}$ This is consistent with the Bruno and Easterly 1998 result that high inflation crises have a strong temporary negative effect on output but no permanent effects.
} 
indicating any causal effect of openness on growth.

Table 8: Panel methods in policies and growth regressions

Dependent variable: Lgdpg

Panel method Random

$\begin{array}{rrrr} & \text { Effects } & & \text { Effects } \\ \text { INFL } & -0.019 & -0.012 & -0.02 \\ & (3.53)^{*} & & (3.43)^{*} \\ * & -0.97 & *\end{array}$

$\begin{array}{llll}\text { BB } & 0.082 & 0.216 & 0.069\end{array}$

$\begin{array}{rrrr} & (2.35)^{*} & (3.51)^{* *} & -1.64 \\ \text { M2 } & 0.002 & 0.026 & -0.057\end{array}$

$\begin{array}{lrrr} & & & (3.16)^{*} \\ \text { LREALOVR } & -0.22 & (2.19)^{*} & * \\ & -0.009 & -0.027 & 0.01 \\ \text { TRADE } & -1.8 & (3.82)^{* *} & -1.43 \\ & 0.012 & 0 & 0.046 \\ & & & (3.19)^{*} \\ \text { LBMP } & -1.95 & -0.07 & * \\ & -0.011 & -0.01 & -0.012 \\ \text { Constant } & (2.15)^{*} & -0.97 & -1.84 \\ & 0.017 & 0.019 & 0.016 \\ & (3.22)^{*} & & \\ \text { Observations } & * & (2.73)^{* *} & -1.61 \\ \text { Number } & 422 & 422 & 422\end{array}$

Number of

$\begin{array}{lrrr}\text { countryno } & 88 & 88 & 88\end{array}$

$\begin{array}{llll}\text { R-squared } & 0.17 & 0.41 & 0.13\end{array}$

Absolute value of $\mathrm{z}$ statistics in parentheses

$*$ significant at $5 \% ; * *$ significant at $1 \%$

Sample Full Full Full

Reject random

effects Yes

Also note that the r-squared of the between regression is much higher than the within regression.

This is not surprising given that the between regression is on averages, but it does show that the growth effects of most concern to policy makers - the change over time within a given country of growth in response to policy changes - are very imprecisely estimated by the data. Fully 87 
percent of the within country variance in growth rates is not explained by these six policy variables. This result is not surprising when we recall the persistence of policies over time and the non-persistence of growth rates.

Another panel method I apply to the data is the well-known dynamic panel estimator of Arellano and Bond. This estimator uses first differences to remove the fixed effects. This method has several advantages: (1) it addresses reverse causality concerns by using twice-lagged values of the right-hand-side variables as instruments for the first differences of RHS variables, (2) we can include initial income again, which is not possible with traditional panel methods because it would be correlated with the error term (Arellano and Bond address this by instrumenting for initial income with the twice-lagged value), and (3) we can also include the lagged growth rate to allow for partial adjustment of growth to policy changes, which is more plausible than instantaneous adjustment.

The results are notable in reinvigorating the conditional convergence hypothesis. This is consistent with previous work that shows a higher coefficient (in absolute value) on initial income with dynamic panel methods than with pooled or cross-section OLS (Caselli, Esquivel, and Lefort 1995). The coefficient on lagged growth is not significant, failing to find support for the partial adjustment hypothesis. The results on policies are similar (not surprisingly) to the fixed effects estimator above. Inflation and trade are strongly significant with the right sign, while M2/GDP still has a significant but perverse sign. The results do not change much if I experiment with omitting one policy variable at a time. The estimates are consistent because I fail to reject that second order serial correlation is zero. The difference with the fixed effects result on policies is that these results have somewhat more claim to being causal. However, the Sargan test rejects the overidentifying restrictions, except in the last equation where I add time dummies. This highlights a weakness of the strong claims for causality made by the dynamic panel method - they depend on the rather dubious assumption that the lagged right-hand side variables do not themselves enter the growth equation. The same problem afflicts the crosssection or pooled regressions that use lagged values of policy as instruments for current policies. Traditionalists who like intuitive arguments why instruments plausibly affect the independent but not the dependent variable are not very persuaded by lagged policies as instruments. As Mankiw 1995 noted sarcastically, if I instrument for the price of apples with the lagged price of 
apples in an equation for the quantity of apples, is it the supply or demand equation that I have identified? 
Table 9: Regressions using Arellano and Bond dynamic panel method

\begin{tabular}{|c|c|c|c|c|}
\hline Dependent variable: lgdpg & (1) & (2) & (3) & (4) \\
\hline \multirow[t]{2}{*}{ LD.lgdpg } & -0.0441 & -0.1131 & -0.09 & -0.0627 \\
\hline & $(0.0749)$ & $(0.0674)^{*}$ & $(0.0771)$ & $(0.0823)$ \\
\hline \multirow[t]{3}{*}{ D.infl } & -0.0137 & -0.0141 & -0.0162 & -0.017 \\
\hline & & & & $(0.0066)^{* *}$ \\
\hline & $(0.0068) * *$ & $(0.0064)^{* *}$ & $(0.0065)^{* *}$ & $*$ \\
\hline \multirow[t]{2}{*}{ D.bb } & 0.1014 & 0.0958 & 0.0876 & 0.0544 \\
\hline & $(0.0509)^{* *}$ & $(0.0501)^{*}$ & $(0.0540)$ & $(0.0571)$ \\
\hline \multirow[t]{2}{*}{ D.m2 } & -0.0701 & -0.0457 & -0.0522 & -0.0486 \\
\hline & $(0.0286)^{* *}$ & $(0.0284)$ & $(0.0302)^{*}$ & $(0.0307)$ \\
\hline \multirow[t]{2}{*}{ D.lrealovr } & 0.0085 & 0.0081 & 0.0083 & 0.0021 \\
\hline & $(0.0093)$ & $(0.0087)$ & $(0.0092)$ & $(0.0098)$ \\
\hline \multirow[t]{2}{*}{ D.lbmp } & -0.0084 & -0.008 & -0.0037 & 0.0013 \\
\hline & $(0.0086)$ & $(0.0081)$ & $(0.0086)$ & $(0.0090)$ \\
\hline \multirow[t]{2}{*}{ D.trade } & 0.0715 & 0.072 & 0.0635 & 0.0555 \\
\hline & $\begin{array}{l}(0.0201)^{* *} \\
*\end{array}$ & $\begin{array}{l}(0.0193)^{* *} \\
*\end{array}$ & $\begin{array}{l}(0.0204)^{* *} \\
*\end{array}$ & $\begin{array}{l}(0.0211)^{* *} \\
*\end{array}$ \\
\hline \multirow[t]{3}{*}{ D.lnewgdp } & & -0.0487 & -0.0508 & -0.0466 \\
\hline & & $(0.0098)^{* *}$ & $(0.0104)^{* *}$ & $(0.0105)^{* *}$ \\
\hline & & $*$ & $*$ & $*$ \\
\hline \multirow[t]{2}{*}{ D.ltyr } & & & 0.0091 & 0.0137 \\
\hline & & & $(0.0104)$ & $(0.0105)$ \\
\hline \multirow[t]{2}{*}{ Constant } & -0.0012 & 0.0014 & 0.0019 & 0.001 \\
\hline & $(0.0016)$ & $(0.0016)$ & $(0.0020)$ & $(0.0021)$ \\
\hline Observations & 323 & 316 & 275 & 275 \\
\hline Number of countryno & 82 & 79 & 69 & 69 \\
\hline Sargan & 36.51018 & 35.57537 & 31.19113 & 23.98194 \\
\hline Prob $>$ chi 2 & 0.0091 & 0.0119 & 0.0385 & 0.1968 \\
\hline \multicolumn{5}{|l|}{ Test First order } \\
\hline autocovariance & 0 & 0 & 0 & 0 \\
\hline \multicolumn{5}{|l|}{ Test Second order } \\
\hline Time dummies & No & No & No & Yes \\
\hline
\end{tabular}

Standard errors in parentheses

$*$ significant at $10 \% ; * *$ significant at $5 \% ; * * *$ significant at $1 \%$

\section{Policy episodes and transition paths}

A more informal approach to detecting the nature of policy effects on growth is to do episodic 
analysis - try to identify major policy reforms and simply examine what happened to growth before and after. The shortcomings of this approach are that we do not control for other factors that affect growth and that it is somewhat arbitrary to define what are "major policy reforms." The advantage is that we can see the annual path of growth rates and thus get a better test of the different prediction for post-reform transitional dynamics made by the models in the theoretical section.

One ambitious attempt to identify major policy reform episodes was made by Sachs and Warner 1995. Sachs and Warner rate an economy as closed if any of the following hold: 1) a black market premium more than 20 percent, 2) the government has a purchasing monopoly at below-market prices on a major commodity export, 3) the country has a socialist economic system, 4) non-tariff barriers cover more than 40 percent of intermediate and capital goods imports, and 5) weighted average tariff of more than 40 percent on intermediate and capital goods. Note that only some of these criteria have anything to do with "trade openness" in the usual sense, as pointed out by Rodriguez and Rodrik 2001. The important thing for my purposes is that Sachs and Warner identify the dates of "reform" according to these criteria. I utilize an updated series of Sachs-Warner openness that goes through $1998 .{ }^{19}$ I pick out countries with at least 13 years of growth data after opening. Since most openings happen towards the end of the sample period, this limits the sample of countries to only 13: Botswana, Chile, Colombia, Costa Rica, Ghana, Guinea, the Gambia, Guinea-Bissau, Israel, Mexico, Morocco, New Zealand, and Papua New Guinea. Figure 7 shows the path of growth and investment before and after opening, after first smoothing each country's series individually with an HP filter. The results do not support any of the above policies and growth models very convincingly. Investment is completely at variance with the predictions for its transitional path. Growth does show a steady acceleration after opening. This could be either a symptom of increasing returns or simply a process of increased credibility as the reforms take hold. Note however that growth was highest many years before the opening. Perhaps the story of closed and open economies is something more complex like temporary high growth under import substitution, which eventually crashed, followed by an opening of the economy and a partial recovery of growth.

\footnotetext{
${ }^{19}$ The source is Easterly, Levine, and Roodman 2003
} 
Growth and investment before and after opening economy in 13 countries

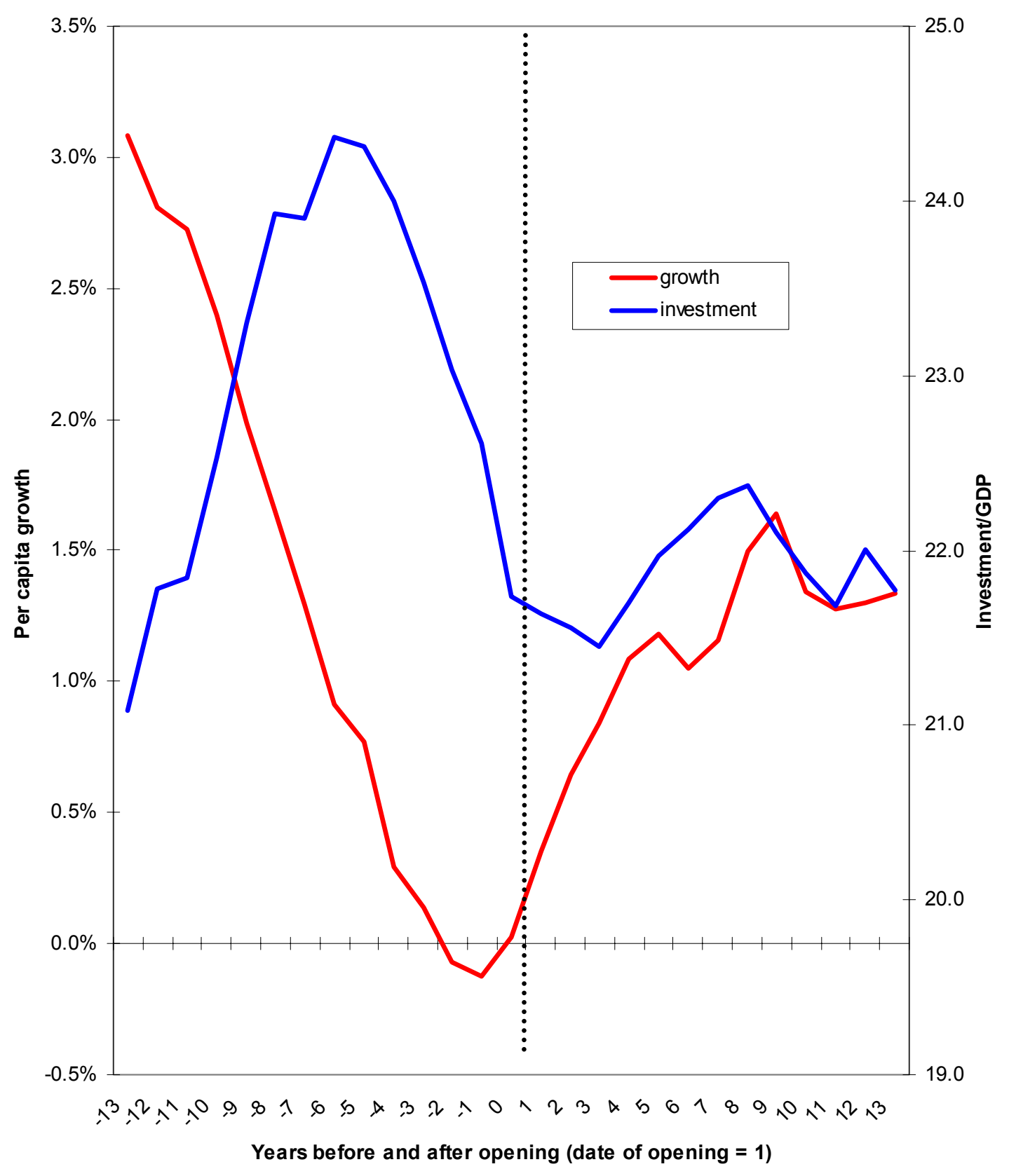

One of the few cases to fit the predictions of growth models as to transitional dynamics is Ghana, where both investment and growth increase after opening. Both keep rising after the date of opening, again supporting either an increasing returns story or increasing credibility of 
Growth and investment before and after opening economy in Ghana

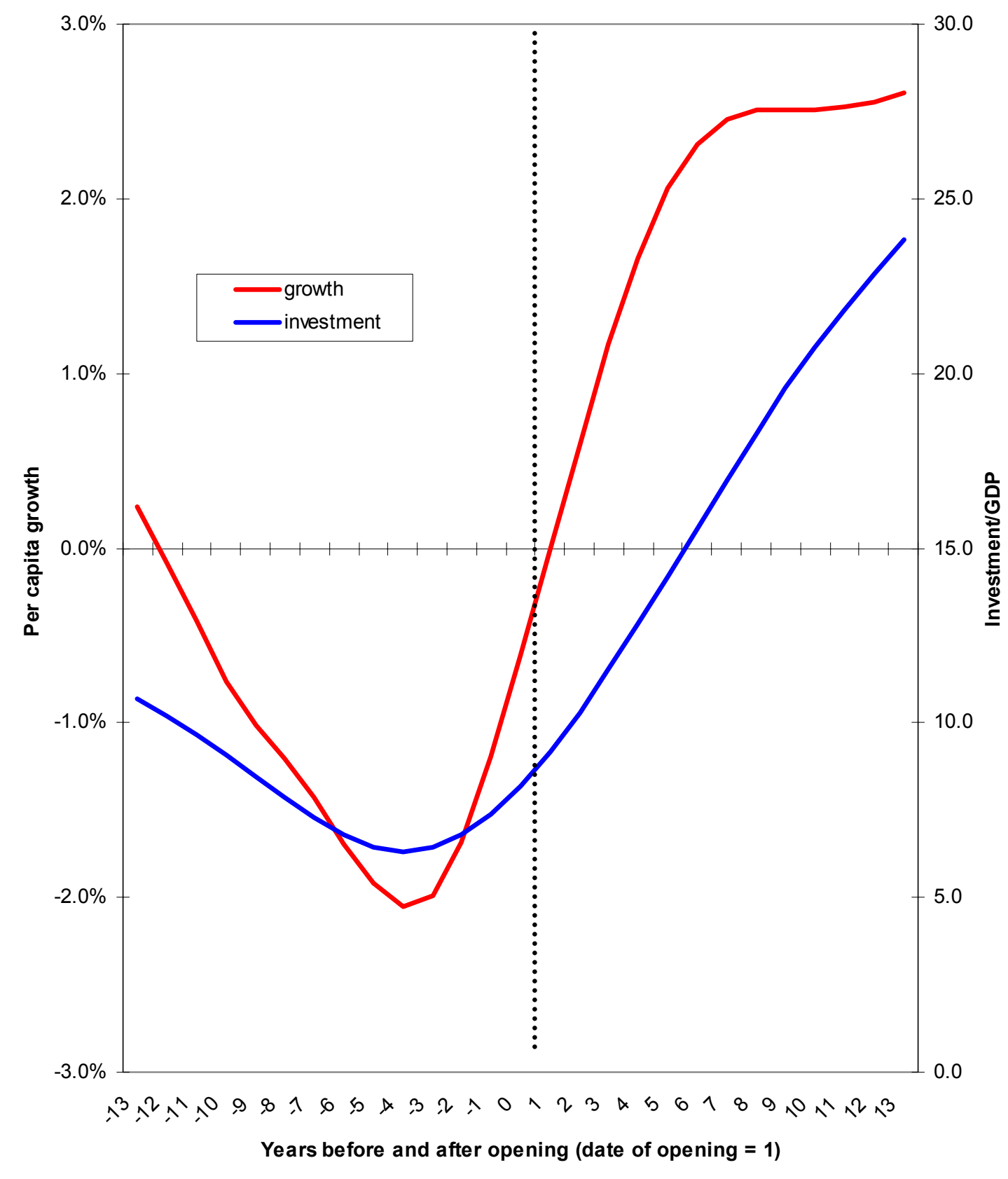

reform. 
Another type of reform that lends itself to transition analysis is stabilization from high inflation. I record episodes of high inflation as following the above definition (log rate of inflation above .3). I measure years of high inflation prior to stabilization, and then years after stabilization when inflation remains below .3. I require that there be at least two years of high inflation to rule out one-time spikes in the price level. The first year after inflation comes down is recorded as year 1. The figure shows the behavior of growth and investment before and after inflation comes down. Growth fits the prediction of theoretical models in jumping to a higher path immediately after inflation comes down. We only have a large enough sample for 7 years after inflation comes down, but growth seems to remain fairly constant post-stabilization. Investment fails to fit the transition predictions of any of the models.

We are left with a somewhat mixed picture. There is a fairly rapid growth effect after policy reform, either accelerating or constant. Investment in physical capital does not seem to respond to reforms in the way predicted by growth models. Of course, causality is up for grabs. There is also still the extreme policies problem, as episodes in which the country was closed or inflation was very high reflect asymmetrically destructive policies; it is not surprising that growth rebounds after these policies are terminated. 
Investment and growth after inflation stabilization

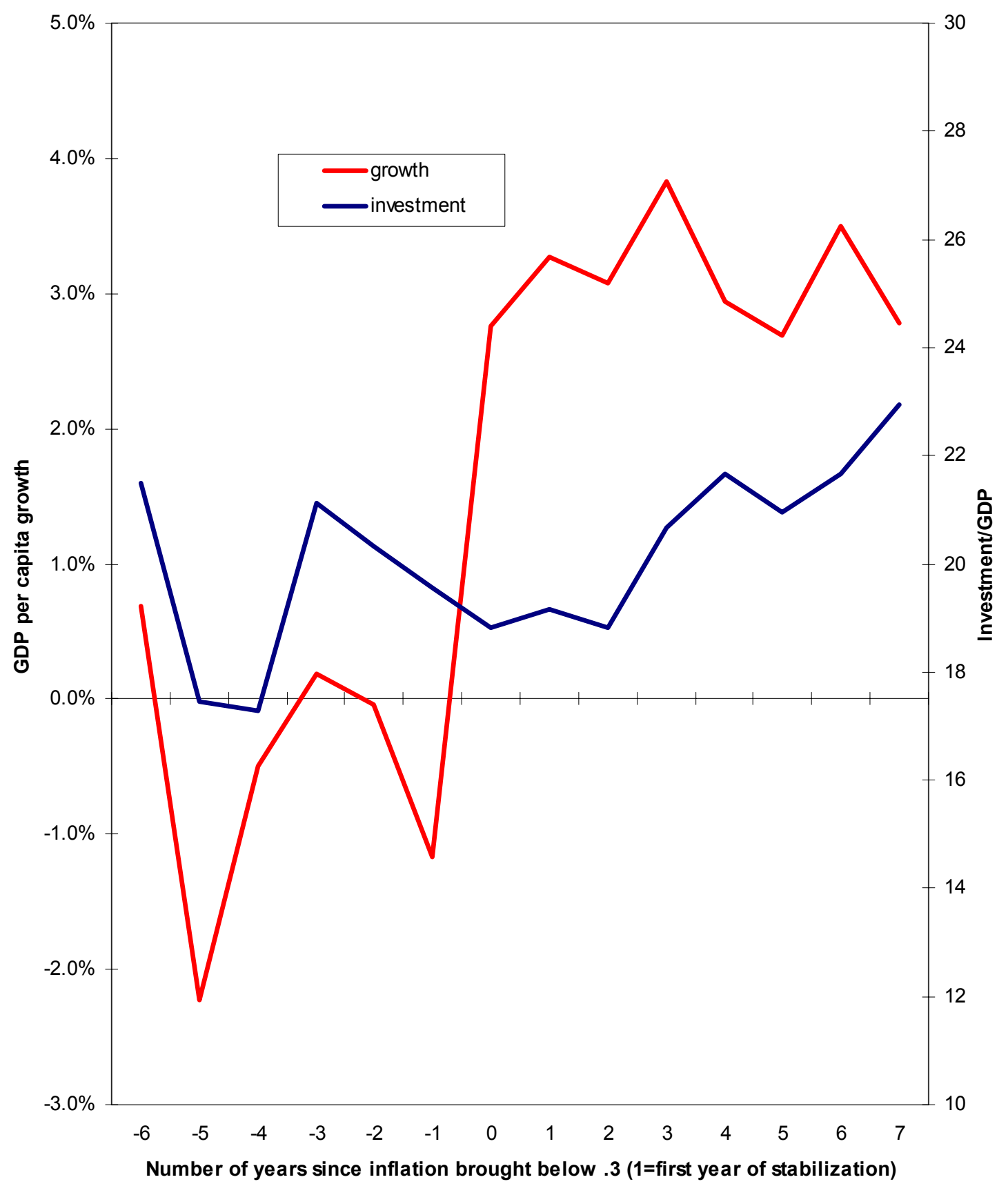




\section{Institutions versus policies}

Recent research has examined the relative role of historical institutions and more recent government policy behavior. The institutions view holds that geographic and historical conditions produce long-lasting differences in institutions. For example, environments where crops are most effectively produced using large plantations will quickly develop political and legal institutions that protect the few landholders from the many peasants (Engerman and Sokoloff 2000). Even when agriculture recedes from the economic spotlight, enduring institutions will continue to thwart competition and hence economic development. Similarly, many countries' institutions were shaped during colonization, so that examining colonies is a natural experiment. European colonialists found different disease environments around the globe. In colonies with inhospitable germs and climates, the colonial powers established extractive institutions, so that a few colonialists could exploit natural resources. In colonies with hospitable climates and germs, colonial powers established settler institutions. According to this view, the institutional structures created by the colonialists in response to the environment endure even with the end of colonialism (Acemoglu, Johnson, and Robinson 2001, 2002). A history of ethnolinguistic divisions may both prevent the development of good institutions and be more damaging when those institutions are absent (Mauro 1995, Easterly and Levine 1997, and Easterly 2001). Thus, the institution view argues that economic development mainly depends on institutions that reflect deep-seated historical factors (North 1992).

In contrast, the policy view - which is really a collection of many different approaches -questions the importance of history or geography in shaping economic development today. This view is embedded in the approach of multilateral development institutions. The policy view holds that economic policies and institutions reflect current knowledge and political forces. Thus, changes in either knowledge about which policies and institutions are best for development or changes in political incentives will produce rapid changes in institutions and economic policies. According to the policy view, while history and geography may have influenced production and institutions, understanding them is not crucial to understanding economic development today.

Easterly and Levine 2003 examine whether major macroeconomic policies - inflation, 
trade policies, and impediments to international transactions as reflected in real exchange rate overvaluation - help explain current levels of economic development, after controlling for institutions. They do this in two steps. First, they treat the macroeconomic policy indicators, which are averaged over the last four decades as exogenous. Simultaneity bias may bias these results toward finding a significant statistical relationship between policies and economic development if economic success tends to produce better policies. Second, they treat the macroeconomic policy indicators as endogenous; they use instrumental variables (geographic variables and ethnolingustic fractionalization) to control for potential simultaneity bias. Using these two methods, they assess whether macroeconomic policies explain cross-country differences in economic development. In both methods they instrument for institutions with the set of variables discussed above.

The evidence suggests that macroeconomic policies do not have a significant impact on economic development after accounting for the impact of institutions on the level of economic development. When the policy variables are treated as included exogenous variables, the Institutions Index enters all of the regression significantly. Furthermore, the coefficient size on the Institutions Index is essentially unchanged from regressions that did not include policy indicators. Thus, even after controlling for macroeconomic policies, institutions explain crosscountry differences in economic development. Furthermore, the data never reject the OIR-test. The policy indicators never enter the regressions significantly. Inflation, Openness, and Real Exchange Rate Overvaluation never enter with a P-value below 0.10. Moreover, even when they are included together, the data do not reject the null hypothesis that the three policies all enter with coefficients equal to zero, which is shown using the F-test on the three policy variables.

When using instrumental variables for the policy indicators, they again find that macroeconomic policies do not explain economic development. Specifically, they fail to reject that hypothesis that macroeconomic policies have zero impact on economic development after accounting for the impact of institutions.

As noted earlier, the instrumental variables explain a significant amount of the crosscountry variation in the Institutions Index. In the first-stage regressions for policy, Easterly and Levine 2003 find that the instruments explain a significant amount of the cross-country variation in Openness and Real Exchange Rate Overvaluation at the 0.01 significance level. However, the 
instruments do not do a very good job of explaining cross-country variation in Inflation, i.e., they fail to find evidence that the instruments explain average inflation rates over the last four decades at the 0.01 significance level. The policy variables never enter significantly in either method. While the exogenous component of the Institutions Index (i.e., the component defined by endowments) continues to significantly account for international differences in the level of GDP per capita, the macroeconomic policy indicators do not add any additional explanatory power.

This raises the suspicion that adverse macroeconomic policies (and macroeconomic volatility in general) may have been proxying for poor institutions in growth regressions. Acemoglu et al. 2003 provide some evidence supporting this suspicion.

In sum, the long run effect of policies on development is difficult to discern once you also control for institutions.

\section{Conclusions}

The large literature on national policies and growth established some statistical association between national economic policies and growth. I confirm that association in this paper and I show how it could have reasonable theoretical foundations. However, I find that the associations seem to depend on extreme values of the policy variables, that the results are not very robust to different econometric methods or introducing initial income, and that a levels regression does not show any effect of policies after controlling for institutions (both instrumented for possible endogeneity). These results are consistent with other theoretical models that predict only modest effects of national policies, depending on model parameters, and show nonlinear effects of tax-cum-subsidy schemes. They are also consistent with the view that the residual "A" explains most of income and growth differences, and it likely reflects deepseated institutions that are not very amenable to change in the short run. 


\section{Bibliography}

Acemoglu, Daron, Simon Johnson, James Robinson, and Yunyong Thaicharoen, Institutional Causes, Macroeconomic Symptoms: Volatility, Crises and Growth, forthcoming, Journal of Monetary Economics, 2003

Acemoglu, Daron, Simon Johnson, and James Robinson, "The Colonial Origins of Comparative Development," American Economic Review, 2001.

Acemoglu, Daron, Simon Johnson, S., James Robinson, 2002. Reversal of fortunes: geography and institutions in the making of the modern world income distribution. Quarterly Journal of Economics 117, forthcoming

Ades, Alberto and Edward Glaeser, "Evidence on growth, increasing returns, and the extent of the market," Quarterly Journal of Economics, Volume CXIV (3), August 1999, pp. 10251046.

Aghion, P. and P. Howitt. Endogenous Growth Theory. MIT Press 1998.

Arellano, Manuel and Bond, Stephen. "Some Tests of Specification for Panel Data: Monte Carlo Evidence and an Application to Employment Equations," Review of Economic Studies

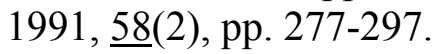

Azariadis, Costas, and Allan Drazen (1990). "Threshold Externalities in Economic Development," Quarterly Journal Of Economics, 105:501-26 May.

Barro, Robert J. 1995. "Inflation and Economic Growth.” Bank of England Quarterly Bulletin (May): 166-76.

Barro, Robert and Xavier Sala-i-Martin (1995). Economic Growth, New York: McGraw-Hill, 1995.

Barro, Robert J. (1998). Determinants of Economic Growth: A Cross Country Empirical Study. Cambridge, MA: MIT Press.

Barro, Robert J. (1991). "Economic Growth in a Cross Section of Countries," Quarterly Journal of Economics 106, 2, 407-443

Barro, Robert and Xavier Sala-i-Martin (1992). “Convergence, ” Journal of Political Economy.

Barro, Robert, J. Mankiw, N. Gregory, and X. Sala-i-Martin (1995). "Capital Mobility in Neoclassical Models of Growth,” American Economic Review, 85:103-15 March.

Beck, Thorsten; Levine, Ross; Loayza, Norman. "Finance and the Sources of Growth," Journal 
of Financial Economics, October/November 2000, 58(1-2), 261-300.

Becker, Gary S., Kevin M. Murphy, and Robert Tamura (1990). "Human Capital, Fertility, and Economic Growth," Journal of Political Economy, Vol. 98, Number 5, Part 2, S12-S37, October.

Bénabou, Roland (1996). "Heterogeneity, Stratification, and Growth: Macroeconomic Implications of Community Structure and School Finance," American Economic Review, 86, No. 3:584-609, June.

Benabou, Roland (1993). "Workings of a City: Location, Education, and Production," Quarterly Journal Of Economics, 108:619-52 August.

Benhabib, J. and M. Spiegel (1994). "Role of Human Capital in Economic Development: Evidence from Aggregate Cross-Country Data," Journal of Monetary Economics, 34: 143-73.

Blomstrom, Magnus, R. Lipsey and M. Zejan (1996). "Is Fixed Investment the Key to Economic Growth?” Quarterly Journal of Economics, February, 269-276.

Borjas, George J. (1999). Heaven's Door: Immigration Policy and the American Economy, Princeton: Princeton University Press, 1999.

Borjas, George J. (1995). "Ethnicity, Neighborhoods, and Human Capital Externalities," American Economic Review, 85, No. 3:365-90 June.

Borjas, George J. (1992). "Ethnic Capital and Intergenerational Mobility," Quarterly Journal of Economics, 107: [123]-50 February.

Boyd, John H.; Levine Ross; Smith, Bruce D. (2001) “The Impact of Inflation on Financial Sector Performance," University of Minnesota, Journal of Monetary Economics (forthcoming).

Bruno, Michael, and Easterly, William. "Inflation Crises and Long-run Growth,” Journal of Monetary Economics 1998, 41, pp. 3-26.

Burnside, Craig (1996). "Production Function Regressions, Returns to Scale and Externalities," Journal of Monetary Economics, 37: 177-200.

Carroll, C.D. and D.N. Weil (1993). "Saving and Growth: A Reinterpretation," CarnegieRochester Series on Public Policy.

Chari, V.V., L. Christiano, and E. McGrattan (1996). "The Poverty of Nations: A Quantitative Exploration," NBER Working Paper No. 5414. 
Collier, Paul and David Dollar. "Can the world cut poverty in half? How policy reform and international aid can meet international development goals," World Development, 2001

De Gregorio, Jose. 1992. "The Effects of Inflation on Economic Growth.” European Economic Review 36 (2-3): 417-24.

-----. 1993. “Inflation, Taxation and Long-Run Growth.” Journal of Monetary Economics 31: 271-98.

Dollar, David. (1992). "Outward-oriented Developing Economies Really Do Grow More Rapidly: Evidence from 95 LDCs, 1976-1985," Economic Development and Cultural Change, 40, 3, 523-544.

Durlauf Steven and Danny Quah. "The New Empirics of Economic Growth." Forthcoming in John Taylor and Michael Woodford (eds), Handbook of Macroeconomics..

Easterly, William and Ross Levine (2003), "Tropics, germs, and crops: the role of endowments in economic development" Journal of Monetary Economics, 50:1, January 2003.

Easterly, William. The Elusive Quest for Growth: Economists' Adventures and Misadventures in the Tropics. Cambridge MA: MIT Press, 2001 (paperback edition 2002).

Easterly, William (2001), "The Lost Decades: Developing Countries' Stagnation in Spite of Policy Reform 1980-98," Journal of Economic Growth.

Easterly, William. (1999b) "The Ghost of Financing Gap: Evaluating the Growth Model of the International Financial Institutions," Journal of Development Economics, December.

Easterly, William and Ross Levine. (2001). "It's Not Factor Accumulation: Stylized Facts and Growth Models," World Bank Economic Review, 2001.

Easterly, William and Ross Levine. (1997a). "Africa's Growth Tragedy: Policies and Ethnic Divisions," Quarterly Journal of Economics November.

Easterly, William "Economic Stagnation, Fixed Factors, and Policy Thresholds," Journal of Monetary Economics 33, 525-557, June 1994.

Easterly, William, Michael Kremer, Lant Pritchett, and Lawrence Summers (1993). "Good Policy or Good Luck? Country Growth Performance and Temporary Shocks." Journal Of Monetary Economics 32:459-83, December.

Easterly, William and Sergio Rebelo. (1993a, "Fiscal Policy and Economic Growth: An Empirical Investigation," Journal of Monetary Economics, 32: 417-458. 
Easterly, William and Sergio Rebelo, "Marginal Income Tax Rates and Economic Growth in Developing Countries," European Economic Review, Vol. 37, pp. 409-417, 1993 b.

Easterly, William. "How Much do Distortions Affect Growth?" Journal of Monetary Economics. Vol. 32, November 1993, 187-212.

Engermann, Stanley and Kenneth Sokoloff (1997), "Factor Endowments, Institutions, and Differential Paths of Growth Among New World Economies: A View from Economic Historians of the United States," in Stephen Haber, ed. How Latin America Fell Behind, Stanford CA: Stanford University Press.

Fischer, Stanley (1993), "The Role of Macroeconomic Factors in Growth.” Journal of Monetary Economics, 32: 485-512.

Frankel, J.A. and Romer, David "Does Trade Cause Growth?" American Economic Review, 1999, 89, pp. 379-399.

Fujita, Masahisa, Krugman, Paul and Anthony Venables (1999). The Spatial Economy: Cities, Regions, and International Trade.

Hall, Robert E. and Charles Jones (1999). "Why Do Some Countries Produce So Much More Output per Worker than Others?" Quarterly Journal of Economics; v114 n1 February, pp. 83-116

Hsieh, Chang-tai (1998). "What Explains the Industrial Revolution in East Asia? Evidence from Factor Markets" Princeton University Woodrow Wilson School Of Public And International Affairs Discussion Papers In Economics No. 196:1-42, January.

International Monetary Fund, Policies for Faster Growth and Poverty Reduction in Sub-Saharan Africa and the Role of the IMF, Issues Brief, Washington DC, 2000

Jalan, Jyotsna and Martin Ravallion (1997). "Spatial Poverty Traps?” World Bank Policy Research Working Paper No. 1862.

Jones, Chad. (1995a) "R\&D-Based Models of Economic Growth, " Journal of Political Economy, August, 103, pp. 759-84.

Jones, Charles. (1995b) “Time Series Tests of Endogenous Growth Models," Quarterly Journal of Economics, May, 105(2), 495-526.

Jones, Charles (1997). Comment on Peter Klenow and Andres Rodriguez-Clare, "The Neoclassical Revival in Growth Economics: Has It Gone Too Far?” NBER Macroeconomics Annual 1997, Volume 12, 73-103. 
Kaufmann, Daniel, Aart Kraay, and Pablo Zoido-Lobatón(1999b) Governance Matters. World Bank Research Working Paper 2196.

King, Robert G. and Ross Levine (1994) "Capital Fundamentalism, Economic Development and Economic Growth,” Carnegie-Rochester Conference Series on Public Policy, 40: 259292.

King, Robert G. and Sergio Rebelo (1993). "Transitional Dynamics and Economic Growth in the Neoclassical Model,” American Economic Review, 83: 908-31.

Klenow, Peter (1998). "Ideas versus Rival Human Capital: Industry Evidence on Growth Models," Journal of Monetary Economics, 42: 2-23.

Klenow, Peter and Andres Rodriguez-Clare (1997a). "Economic Growth: A Review Essay," Journal of Monetary Economics, 40: 597-617.

Klenow, Peter and Andres Rodriguez-Clare (1997b). "The Neoclassical Revival in Growth Economics: Has It Gone Too Far?” NBER Macroeconomics Annual 1997, Volume 12, 73-103.

Klitgaard, Robert and Amand Fitschen (1997). "Exploring Income Variations across Traditional Authorities in KwaZulu-Natal, South Africa," Development Southern Africa, Vol. 14, No. 3, October.

Kosmin, Barry A. and Seymour P. Lachman (1993). One Nation Under God: Religion in Contemporary American Society, Harmony Books.

Kremer, Michael (1993). "O-ring Theory of Economic Development,"Quarterly Journal Of Economics, 108:551-75 August.

Krugman, Paul (1998). "Space: The Final Frontier." Journal Of Economic Perspectives, 12:16174, Spring 1998

Krugman, Paul (1995). Development, Geography, and Economic Theory, Cambridge, MA: MIT Press.

Krugman, Paul R. (1991). Geography and Trade, Cambridge MA: MIT Press.

Krugman, Paul $R$ and Anthony J.Venables (1995). "Globalization and the Inequality of Nations" Quarterly Journal of Economics, November, pp. 857-80.

La Porta, R., Lopez-de-Silanes, F., Shleifer, A., Vishny, R.W., 1999. The quality of government. 
Journal of Law, Economics, and Organization 15, 222-279.

La Porta, R., Lopez-de-Silanes, F., Shleifer, A., Vishny, R.W., 1998. Law and finance. Journal of Political Economy 106, 1113-1155

Levine, Ross; Loayza, Norman; Beck, Thorsten. "Financial Intermediation and Growth: Causality and Causes," Journal of Monetary Economics, August 2000, 46, 31-77.

Levine, Ross and Sara Zervos. (1998). "Stock Markets, Banks, and Economic Growth," American Economic Review, 88, 537-58.

Levine, Ross and Sara J. Zervos. (1993). "What We Have Learned about Policy and Growth from Cross-Country Regressions?” American Economic Review, 83, 2, 426-430.

Levine, Ross and David Renelt (1992), "A Sensitivity Analysis of Cross-Country Growth Regressions," American Economic Review, September, 82(4), pp. 942-63.

Lucas, Robert E., Jr. (1988). “On the Mechanics of Economic Development,” Journal of Monetary Economics, 22: 3-42.

Lucas, Robert E., Jr. (1990). Why Doesn't Capital Flow from Rich to Poor Countries? American Economic Review, Papers And Proceedings, 80:92-96 May.

Lucas, Robert E. Jr. (1998) “The Industrial Revolution: Past and Future.” Mimeo.

Maddison, Angus (1995). Monitoring the World Economy, 1820-1992, Paris : Development Centre of the Organisation for Economic Co-operation and Development.

Mankiw, N. Gregory (1995). "The Growth of Nations," Brookings Papers on Economic Activity 1, pp. 275-326.

Mankiw, N. Gregory, David Romer, David N. Weil (1992). "Contribution to the Empirics of Economic Growth,” Quarterly Journal Of Economics, 107:[407]-37.

McGrattan, Ellen R. (1998) “A defense of AK growth models.” QUARTERLY REVIEW / FEDERAL RESERVE BANK OF MINNEAPOLIS 22:13-27, Fall

McGrattan, Ellen and James Schmitz (1998). "Explaining Cross-country Income Differences," Federal Reserve Bank of Minneapolis, Research Department, mimeo, June.

Murphy, Kevin M., Andrei Shleifer, Robert Vishny (1989). "Industrialization and the Big Push," Journal Of Political Economy, 97:1003-26. 
Parente, Stephen (1994). "Technology Adoption, Learning-by-Doing, and Economic Growth," Journal of Economic Theory, 63: 346-69.

Parente, S.L. and Prescott, E.C. (1996) "Barriers to Technology Adoption and Development," Journal of Political Economy, 102(2), pp. 298-321.

Patrinos, Harry Anthony (1997). "Differences in Education and Earnings Across Ethnic Groups in Guatemala," Quarterly Review of Economics and Finance, 37 (4).

Prescott, Edward (1998). “Needed: A Theory of Total Factor Productivity,” International Economic Review, forthcoming.

Pritchett Lant. (1999). "The Tyranny of Concepts: CUDIE (Cumulated, Depreciated, Investment Effort) is Not Capital", World Bank mimeo.

Pritchett, Lant (1998). "Patterns Of Economic Growth : Hills, Plateaus, and Mountains," World Bank Development Research Group Policy Research Working paper No. 1947.

Pritchett, Lant (1997). "Where Has All the Education Gone?” World Bank Policy Research Working Paper No. 1581.

Psacharopoulos, George (1994). "Returns to Investment in Education: A Global Update," World Development, Vol. 22, No. pp. 1325-1343.

Psacharopoulos, George and Harry Anthony Patrinos (1994). "Indigenous People and Poverty in Latin America," Human Resources Development and Operations Policy Working Paper \#22.

Rebelo, Sergio. (1991). “Long Run Policy Analysis and Long Run Growth,” Journal Of Political Economy, 99, 500-521.

Quah, Danny. "Galton's Fallacy and Tests of the Convergence Hypothesis." Scandinavian Journal of Economics; v95 n4 December 1993, pp. 427-43.

Rauch, James E. (1993). "Productivity Gains from Geographic Concentration of Human Capital: Evidence from the Cities," Journal Of Urban Economics, 34:380-400.

Ravallion, Martin and Jyotsna Jalan (1996). "Growth Divergence Due to Spatial Externalities," Economics Letters 53, 227-232.

Ravallion, Martin and Quentin Wodon (1998). “Poor Areas or Only Poor People?" mimeo World Bank. 
Ray, Debraj (1998). Development Economics. Princeton: Princeton University Press.

Rebelo, Sergio (1991) “Long-run Policy Analysis and Long-run Growth," Journal of Political Economy 99, 500-521.

Rebelo, Sergio (1998). "The Role of Knowledge and Capital in Economic Development," Northwestern University, mimeo.

Rebelo, Sergio and Nancy L. Stokey (1995). "Growth Effects of Flat-rate Taxes,” Journal Of Political Economy, 103:519-50.

Rodrik, Dani (1998). "Where Did all the Growth Go? External Shocks, Social Conflict and Growth Collapses," National Bureau Of Economic Research. Working Paper Series No. 6350 .

Romer, Paul (1995). Comment on N. Gregory Mankiw, "The Growth of Nations," Brookings Papers on Economic Activity 1, pp. 313-320.

Romer, Paul (1990). “Endogenous Technological Change,” Journal of Political Economy, 98: S71-S102.

Romer, Paul (1986). “Increasing Returns and Long-Run Growth,” Journal of Political Economy, 94: 1002-37.

Sachs, J. and A. Warner (1995) "Economic Reform and the Process of Global Integration" Brookings Papers on Economic Activity, 1, 1-95.

Sarel, Michael. 1996. "Nonlinear effects of inflation on economic growth," IMF Staff Papers 43:199-215, March

Shleifer, Andrei and Robert Vishny (1993). "Corruption," Quarterly Journal of Economics, 108(3): 599-667.

Sokoloff, Kenneth L. and Stanley L. Engerman (2000), Institutions, Factor Endowments, and Paths of Development in the New World, Journal of Economic Perspectives v14, n3, 217-32.

Solow, R. (1957). "Technical Change and the Aggregate Production Function," Review of Economics and Statistics, 39: 312-20.

Solow, R. (1956). "A Contribution to the Theory of Economic Growth," Quarterly Journal of 
Economics, 70: 65-94.

Young, Alwyn (1995). "The Tyranny of Numbers: Confronting the Statistical Realities of the East Asian Growth Experience," Quarterly Journal of Economics, 110: 641-680.

Woolcock, Michael, and Deepa Narayan. 2000. "Social Capital: Implications for Development Theory, Research, and Policy.” World Bank Research Observer 15(2): 225-49.

World Bank, 1981, Accelerated Development in Sub-Saharan Africa. Washington DC 


\section{Center for Global Development Working Papers}

No. 1, January 2002 Inequality Does Cause Underdevelopment: New Evidence, William Easterly

No. 2, January 2002

HIV/AIDS and the Accumulation and Utilization of Human Capital in Africa, Amar Hamoudi and Nancy Birdsall

No. 3, February 2002

External Advisors and Privatization in Transition Economies, John Nellis

No. 4, March 2002

The Cartel of Good Intentions: Bureaucracy versus Markets in Foreign Aid, William Easterly

No. 5, April 2002

Intellectual Property and the Availability of Pharmaceuticals in Developing Countries, Jean O. Lanjouw

No. 6, May 2002

Winners and Losers: Assessing the distributional impacts of privatization, John Nellis and Nancy Birdsall

No. 7, May 2002

Commodity Dependence, Trade, and Growth: When 'Openness' is Not Enough, Nancy Birdsall and Amar Hamoudi.

No. 8, June 2002

Financial Crises and Poverty in Emerging Market Economies, William Cline

No. 9, August 2002

An Identity Crisis? Testing IMF Financial Programming, William Easterly

No. 10, Sept. 2002

Solutions when the Solution is the Problem: Arraying the Disarray in Development, Lant Pritchett and Michael Woolcock

No. 11, October 2002

What did structural adjustment adjust? The association of policies and growth with repeated IMF and World Bank adjustment loans, William Easterly

No. 12, October 2002 Asymmetric Globalization: Global Markets Require Good Global Politics, Nancy Birdsall

No. 13, October 2002

Low Investment is not the Constraint on African Development, Shantayanan Devarajan, William Easterly, Howard Pack

No. 14, October 2002 An Index of Industrial Country Trade Policy toward Developing Countries, William R. Cline

No. 15, October 2002 Tropics, Germs, and Crops: How Endowments Influence Economic Development, William Easterly and Ross Levine 
No. 16, October 2002

Do As I Say Not As I Do: A Critique Of G-7 Proposals On Reforming The $M D B s$, Devesh Kapur

No. 17, October 2002 Policy Selectivity Foregone: Debt and Donor Behavior in Africa, Nancy Birdsall, Stijn Claessens and Ishac Diwan

No. 18, Nov. 2002

Private Sector Involvement in Financial Crisis Resolution: Definition, Measurement, and Implementation, William R. Cline

No. 19, Dec. 2002

Do Rich Countries Invest Less in Poor Countries Than the Poor Countries Themselves?, Michael A. Clemens

No. 20, December 2002 World Bank capital neither complements nor substitutes for private capital, Michael A. Clemens

No. 21, December 2002 From Social Policy to an Open-Economy Social Contract in Latin America, Nancy Birdsall

No. 22, January 2003

Global Economic Governance and Representation of Developing Countries: Some Issues and the IDB Example, Nancy Birdsall

No. 23, February 2003 The Millennium Challenge Account: How much is too much, how long is long enough?, Michael A. Clemens and Steve Radelet

No. 24, February 2003 Bootstraps Not Band-Aids: Poverty, Equity and Social Policy in Latin America, Nancy Birdsall and Miguel Szekely

No. 25, February 2003 Privatization in Africa: What has happened? What is to be done?, John Nellis

No. 26, March 2003 New Data, New Doubts: Revisiting “Aid, Policies, and Growth”, William Easterly, Ross Levine, David Roodman 